\title{
Agricultural seasonality, market access, and food security in Sierra Leone
}

\author{
Isaac Bonuedi ${ }^{1}$ D . Lukas Kornher ${ }^{1}$ (D) . Nicolas Gerber ${ }^{1}$ (D
}

Received: 18 December 2020 / Accepted: 10 November 2021 / Published online: 26 November 2021

(c) The Author(s) 2021

\begin{abstract}
Seasonal variations in agriculture is a major contributor to undernutrition in many agrarian economies. While recent studies have highlighted the role of markets in improving nutrition, the relative importance of markets in smoothing food consumption across seasons remains largely unexamined. Using data from Sierra Leone, this paper analyses whether access to local food markets mitigates seasonal fluctuations in household dietary diversity and food security. Our results confirm that agricultural seasonality imposes significant fluctuations on household dietary diversity and food security. Households, especially those in rural areas, are found to experience significant deteriorations in dietary diversity and food security during the lean season. Most importantly, the results also show that households with better market access consume more diverse diets and are more food secure in both lean and non-lean seasons than remoter households. An important policy implication of these results is that market-based interventions aimed at strengthening market access through improved market infrastructure and roads can significantly contribute to year-long food consumption smoothing, improved dietary diversity and overall food and nutrition security.
\end{abstract}

Keywords Seasonality $\cdot$ Market access $\cdot$ Dietary diversity $\cdot$ Food security $\cdot$ Sierra Leone

JEL Codes $\mathrm{Q} 10 \cdot \mathrm{Q} 13 \cdot \mathrm{Q} 18 \cdot \mathrm{I} 30$

\section{Introduction}

Achieving food security requires that people have access at all times to adequate nutritious foods to meet their dietary needs for a healthy and active life. However, not everyone in the world has stable, all-year-round access to enough safe and nutrient-rich food. Millions of people, mostly smallholder farmers in agrarian economies, are afflicted by seasonal food insecurity every year, primarily because of cyclical fluctuations in food availability and access (Devereux et al., 2008). Unlike conflict, climate variability and extremes and natural catastrophes, seasonality is often

Isaac Bonuedi

s7isbonn@uni-bonn.de

Lukas Kornher

lkornher@uni-bonn.de

Nicolas Gerber

ngerber@uni-bonn.de

1 Center for Development Research (ZEF), Genscherallee 3, D- 53113 Bonn, Germany neglected as a significant contributor to food insecurity and malnutrition, even though it is a common cause and its impacts are not insignificant (Devereux et al., 2012; Vaitla et al., 2009).

Seasonality is characteristic of rural livelihood in developing countries, where majority of the world's poor, food insecure and malnourished people live and depend primarily on rain-fed agriculture (Devereux et al., 2012; Khandker \& Mahmud, 2012). Household income, food security and nutrition, and other welfare outcomes in these agrarian settings exhibit noticeable seasonal disparities, driven by regular patterns of the agricultural cycle. They improve markedly in immediate postharvest months when food supply and purchasing power abound, and deteriorate sharply in pre-harvest months, particularly during the so-called 'lean' or 'hunger' season (Handa \& Mlay, 2006; Sibhatu \& Qaim, 2017). During this lean season period, which often coincides with the rainy season in many low-income countries, food stocks from the previous harvest are depleted, markets become inaccessible, food prices rise steeply, wages plummet, and incomegenerating avenues become limited (Khandker \& Mahmud, 
2012; Vaitla et al., 2009). The hardest hit are vulnerable and poor households, who are unable to insure their consumption against fluctuations in production and income (Alderman \& Paxson, 1994; Dercon, 2002; Dercon \& Krishnan, 2000). In particular, these households often do not have adequate buffer food reserves, or past savings, or access to credit, remittances or social protection schemes to smooth consumption all year round (Alderman \& Paxson, 1994; Khandker \& Samad, 2016).

In the face of financial constraints, they are often coerced to sell their produce at low prices in postharvest months and purchase them back, a few months later, at higher prices during the lean season (Burke et al., 2019; Stephens \& Barrett, 2011). These seasonality effects may also spread to urban areas as limited food supply (from remote, rural areas) leads to food price inflation and negative dietary and nutritional adjustments (Anderson et al., 2018; Gilbert et al., 2017). Furthermore, by compelling households to adopt negative coping strategies (such as depleting their assets or going into debt), seasonality may exacerbate their vulnerability to poverty and undermine their resilience to adverse shocks (Alderman \& Paxson, 1994; Dercon, 2002). What is more debilitating is the adoption of deleterious consumptionrelated coping strategies to mitigate seasonal food stress. These may include the rationing of available food and changing the quality (diversity), quantity, and frequency of their diets (Maxwell \& Caldwell, 2008).

Dietary changes involving the consumption of less nutritious and highly monotonous diets (e.g., largely cereal- or tuber-based) may quickly fill the stomach and dispel hunger pangs, but compromise dietary quality and increase the risk of micronutrient deficiencies. Such short-term food deprivations (nutritional shocks) may have long-term consequences for individuals, especially pre-schooling children (Alderman et al., 2006). In particular, children that repeatedly experience seasonal hunger are at high risk of undernutrition, including insufficient micronutrient intake (or hidden hunger). Undernutrition, in turn, weakens their immune systems and irreversibly stunts their cognitive and physical development - with undesirable consequences of reduced productivity, educational attainment, and earning potential as adults (Bhutta et al., 2013).

Among several potential policy approaches to tackle seasonality, and its attendant food insecurity (Khandker et al., 2012; Vaitla et al., 2009), emerging literature underscores the primacy of market access in improving dietary and nutritional outcomes, especially of poor, vulnerable and food insecure households (Headey et al., 2019; Hirvonen et al., 2017; Sibhatu \& Qaim, 2017). Both rural and urban households trade in local markets either as sellers of own produce or buyers of food produced by others (or both). Conceptually, well-functioning and easily accessible markets can contribute to overall food and nutrition security by ensuring consistent availability of and economic access to diverse nutritious foods at affordable prices. Furthermore, nearness to markets may increase the time available for proper feeding and care practices (Johnston et al., 2018; Komatsu et al., 2018; Ruel \& Alderman, 2013); reduce food prices and transportation costs, thus increase household's effective purchasing power and demand for diverse diets (Usman \& Callo-Concha, 2021); and boost productivity and farm diversification through improved access to productive inputs (Dorosh et al., 2003). Evidence from previous studies accentuates the importance of access to markets and commercialization for dietary quality, food security and livelihoods of rural households (Abay \& Hirvonen, 2017; Handa \& Mlay, 2006; Headey et al., 2019; Hirvonen et al., 2017; Koppmair et al., 2017; Ogutu et al., 2019; Sibhatu \& Qaim, 2017; Sibhatu et al., 2015; Stifel \& Minten, 2017; Zanello et al., 2019). In particular, these studies have largely shown that proximity to markets or increased commercialization has significant positive effects on food security and dietary diversity at household and individual levels as well as on children's nutritional status.

However, there is limited evidence on the role of market access in mitigating seasonal fluctuations in household dietary diversity and food security. The empirical research on seasonality and market access have so far been carried out in separate silos. Only a handful of studies have attempted to unify these two strands of literature (Abay \& Hirvonen, 2017; Handa \& Mlay, 2006; Sibhatu \& Qaim, 2017; Zanello et al., 2019). Abay and Hirvonen (2017) reported that market access improves dietary diversity but does not reduce seasonal fluctuations in Ethiopian children's anthropometrics. For rural Ethiopian households, Sibhatu and Qaim (2017) showed that purchased foods constitutes over half of household calorie intake during the lean season. Zanello et al. (2019) found that, in Afghanistan, while cropping diversity matters for dietary diversity during the regular season, market food availability improves dietary diversity in the lean season. Lastly, Handa and Mlay (2006) demonstrated that proximity to road enables Mozambican households to smooth their consumption over the agricultural cycle.

Apart from these few studies that looked at the interaction between seasonality and market access and their impact on food and nutrition security, we are not aware of any other study that has examined these interactions in the post-war context with prevailing limitations in rural infrastructure. In particular, to what extent the effect of markets on dietary diversity and food security varies at different times of the year is not well understood. A possible reason is that most existing studies were based on data collected at one point in time during the year. Obtaining a better understanding of the seasonal implications of markets for nutrition will help improve knowledge and policy. We address this important research gap with data from Sierra Leone, a post-conflict 
West African country, characterized by pervasive agricultural seasonality, malnutrition, and food insecurity and major constraints on market access. The study employs recent nationally representative data from the Sierra Leone Integrated Household Survey (SLIHS) to study the potential protective effects of improved market access against seasonal deteriorations in household dietary diversity and food security.

The remainder of this paper is organised as follows. Section 2 presents a conceptual framework that links seasonality, markets and food security. Section 3 provides a contextual overview of seasonality, market access, and food security in Sierra Leone. Section 4 discusses the data and methods, and the results are presented and discussed in Sect. 5. Section 6 concludes the study with key findings and policy implications.

\section{Conceptual linkages among seasonality, market access, and food security}

In agricultural household models, the separability assumption of interlinked household decisions on production, consumption, labor allocation, and leisure is relaxed. Therefore, households are assumed to maximize their expected utility of consumption of on-farm food produce and other consumption goods that must be bought in the marketplace, given these interlinkages and the associated constraints. In a dynamic setting with seasonal agricultural production, the household must decide how to meet its consumption needs both in each year's harvest as well as lean seasons (Saha, 1994; Stephens $\&$ Barrett, 2011). For risk-averse households, maximizing inter-temporal utility leads to precautionary savings equating expected marginal utilities across seasons. Thus, all things being equal, households will prefer smoothing consumption over time, (Stephens \& Barret, 2011; Dercon \& Krishnan, 2000). When households have access to well-functioning markets, these preferences will lead to a stable optimal consumption path. However, if markets are incomplete or nonexistent, and credit constraints are binding, consumption will be subjected to fluctuations in income or purchasing power, due to, for instance, seasonality- or shock-induced variabilities in prices and wages.

In the absence of complete formal insurance and financial markets and effective social protection, (poor) households and individuals undertake a wide range of risk management and coping actions to limit the variability of income and consumption (Alderman \& Paxson, 1994). The risk management strategies are directed at income smoothing, for instance, through diversification (livelihoods, crops, or fields) or attempting to earn extra income (by temporarily migrating, or taking additional jobs). The goal of risk coping strategies is to smooth consumption over time. These include self-insurance (through the accumulation or depletion of savings, assets, or buffer stocks), borrowing, and informal risk-sharing arrangements that involve mutual support between family networks, groups, or communities (Alderman \& Paxson, 1994; Dercon, 2002; Dercon \& Krishnan, 2000).

When these mechanisms fail, consumption smoothing does not happen, as households are unable to fully insure consumption against fluctuations in income or purchasing power. Seasonal food insecurity is partly a manifestation of the failure to achieve year-round smoothing of food consumption. This may be due to agricultural seasonality and the associated delay between the planting and harvesting of staple food crops, which have different seasonal production cycles (Khandker et al., 2012). Consequently, the months leading up to harvest are often characterized by depletion of food stocks (from own-production), high food prices, limited employment avenues for agricultural workers, and loss of livelihoods, income and other entitlements to foods (Devereux et al., 2012; Khandker \& Samad, 2016). With production patterns being strongly determined by agroclimatic conditions and the level of agricultural technology applied, seasonality and its resultant seasonal food stress will be more intense in areas with rain-fed, monocrop agriculture, than in more favorable locations that permit multiple cropping, and farm diversification, and are less reliant on erratic rainfall for irrigation (Abay \& Hirvonen, 2017).

Seasonal food deprivation is also related to market inefficiencies arising from poor market and infrastructural conditions which prevent certain households from accessing food even in times of abundant food availability (Devereux et al., 2012; Khandker \& Mahmud, 2012; Khandker et al., 2012). Most agricultural households in the developing world are located in geographically isolated areas with weak connectivity to formal market institutions, poor-quality transport, and other market-related infrastructure (Fafchamps \& Hill, 2005; Stifel \& Minten, 2017). These poor market conditions, coupled with isolation, increase transaction costs (e.g., transport, time, and search costs), and hurt households in a number of ways. For instance, the associated high transaction costs can inhibit market integration, resulting in incomplete price transmission and reduction of information available to economic actors, which in turn lead to decisions that contribute to inefficient outcomes (Abdulai, 2000; de Janvry et al., 1991; Moser et al., 2009). These include higher output and input prices, reduced movements of farm products and other goods, erosion of gains from trade; lower agricultural production due to limited access to and adoption of modern productivity-enhancing inputs and technologies, adoption of low-yielding food crops instead of high-value cash crops, huge postharvest losses at the farmgate, and lower accessibility, availability and diversity of foods on local markets, particularly in remote locations. 
Improving access to markets (by means of better transport and communication infrastructure) can contribute to food consumption smoothing by enhancing physical and economic access to food, as well as the availability of foods in the market across seasons. This may occur through several mechanisms. First, better access to markets lowers transaction costs, and facilitates market participation (or commercialization), as well as the movement of fresh, healthy foods from local and international markets to food deficit areas (Bonuedi et al., 2020; Fafchamps \& Hill, 2005). With transport costs being lower in the dry season (when roads are passable) than in the rainy season (when they are not) (Cramon-Taubadel, 2017), improved market access can also foster consistent availability of nutritious foods in the marketplace and thus lower the seasonality of food availability, access and consumption (Zanello et al., 2019). Second, offfarm avenues are scarcer in more remote areas. However, improved market access increases opportunities for seasonal migration and (temporary) off-farm income-generating activities, which may enhance the ability of households to access healthy foods at all times (Handa \& Mlay, 2006; Jacoby \& Minten, 2009). Last but not least, access to (product) markets may also improve access to credit (in the form of cash, inputs, or food), thereby enabling households to smooth consumption across seasons (Schrieder \& Heidhues, 1995; Zeller et al., 1997).

\section{Study context}

Located in Western Africa, Sierra Leone is inhabited by approximately 7 million people (Taqi et al., 2017). It borders Guinea to the north-east, Liberia to the south-east, and the Atlantic Ocean to the south-west The country has a tropical - hot and humid - climate with two distinct seasons: a rainy season from May to October and a dry season from November to April (Amadu et al., 2017). The average annual rainfall is around $3000 \mathrm{~mm}$, with July and August being the dampest months $(450-540 \mathrm{~mm})$. Monthly temperature ranges from 25 to $34{ }^{\circ} \mathrm{C}$ and averages around 26 ${ }^{\circ} \mathrm{C}$. In December and January, when the cold, dry, and dusty Harmattan wind blows from the Sahara, the temperature could drop to about $16{ }^{\circ} \mathrm{C}$ at night (Dossou-Yovo et al., 2017; World Bank Climate Change Knowledge Portal, 2019).

The last four decades have seen an interaction of several factors hampering the country's economic development, thereby leaving it among the poorest economies in the world. Notable among these factors are the decade-long civil war (1992-2001), exogenous shocks (e.g., the Ebola epidemic, mudslides, and the collapse of commodity prices), and entrenched structural and institutional constraints. As a low-income country, it has an income per capita of $\$ 474$ and ranks 184th out of 189 countries in terms of human development (UNDP, 2016). In 2017, almost two-thirds of its populace were identified to be poor in multiple dimensions, with the incidence of poverty more pronounced in rural areas $(86.3 \%)$ than urban areas $(37.6 \%)$ (Statistics Sierra Leone, 2019b). Despite making progress over the years, the food insecurity situation in the country remains alarming with almost half (49.8\%) of its households lacking access to sufficient nutritious of foods (World Food Programme, 2015). The precarious state of food security in the country is manifested in high rates of stunting (affecting over $30 \%$ of under-five children (Ministry of Health and Sanitation \& Action Against Hunger, 2017)) and under-five mortality (94 deaths per 1,000 per live births (Statistics Sierra Leone \& UNICEF Sierra Leone, 2017). This is also seen in the poor performance on the Global Hunger Index, with the country ranking 114th out of 119 countries (von Grebmer et al., 2018).

Agriculture is the mainstay of Sierra Leone's economy, accounting for two-thirds of employment and gross domestic output (GDP) (Gboku et al., 2017). The country's leading food crops are rice, cassava, maize, millet, sweet potato, and groundnut. These are mainly cultivated by smallholder farmers manning 0.5-2 hectares of farmland (Amadu et al., 2017). Approximately $85 \%$ of farmers cultivate rice, the most important staple food crop, consumed daily throughout the country (Ministry of Agriculture, Forestry \& Ministry of Health and Sanitation, 2016). The next most significant food crop, cultivated by $77.2 \%$ of rural households, is cassava. Cassava and the other minor staples are widely and frequently consumed, particularly to meet household energy needs when rice is scarce (World Food Programme, 2011). Dark green leafy vegetables like cassava leaves and potato leaves are key ingredients in household diets. Over $60 \%$ of households consume from their production (Statistics Sierra Leone, 2014). This suggests that subsistence farming constitutes an essential source of food for many households in the country. As a result, seasonal variations can have significant effects on household food availability, consumption, and, ultimately, nutritional status.

The seasonality of food security is quite evident in Sierra Leone. The food security situation varies in parallel with the agricultural production cycle, as most people derive their livelihoods from agriculture. As Binns and Bateman (2017) observed, there is a long-standing, regular pattern of cyclical food insecurity among many households. Households, in both rural and urban areas, are most vulnerable to hunger during the 'lean season' or 'hunger gap' (June-September), when there is increased demand for labour for agricultural activities, food stocks are lowest, commerce slumps, food prices soar, and rainfall is torrential, thereby making most (rural) roads impassable and markets physically inaccessible. It is also the time of the year when there is a high prevalence of sickness (mainly malaria and diarrheal diseases), 
malnutrition, indebtedness, distress, destitution, and exploitation. The month of August is the peak of the hunger gap during which the percentage of households reporting inadequate household food provisioning is highest, reaching $80 \%$ in urban areas and over $90 \%$ in rural areas (Bonuedi, 2021; World Food Programme, 2011). However, this proportion plummets sharply (i.e., to below $4 \%$ ) in the subsequent months, mainly due to increased food availability from the harvest of food crops (Bonuedi, 2021).

Infrastructure in Sierra Leone suffered severely from the protracted armed conflict. Despite investing \$134 million annually, since the war ended, to rebuild and modernize infrastructure (Pushak \& Foster, 2011), the nation's stock of infrastructure remains inadequate and poorly maintained. In particular, Sierra Leone's progress towards recovery and sustained economic development is severely hindered by poor-quality roads, weak transport infrastructure, and poor road connectivity (FEWS NET, 2017; Pushak \& Foster, 2011). These poor infrastructural conditions, coupled with the consequent high transaction costs, obstruct people's access to markets (for inputs, produce, and credit), the transportation of goods, inputs and people, as well as, access to new income-earning opportunities and social services. Of particular interest in this study is the access to product markets, which is a critical determinant of food security. Market access is generally measured in the literature in terms of distance, time, and costs of traveling to the nearest market, town/urban centre or all-season road (Abay \& Hirvonen, 2017; Headey et al., 2019; Hirvonen et al., 2017; WFP, 2017). According to the 2015 Sierra Leone Comprehensive Food Security and Vulnerability Analysis (CFSVA) survey, $83 \%$ of Sierra Leone households live in communities with no functional market (WFP, 2015). On average, households had to travel (usually by foot) about $83 \mathrm{~min}(\approx 7.8$ miles or $12.6 \mathrm{~km}$ ) to reach the nearest market. In terms of road access, they had to travel by road transport for about $180 \mathrm{~min}$ $(\approx 10.43$ miles or $16.7 \mathrm{~km}$ ) reach the nearest road by a road transport). This low market penetration (or high isolation) means that households have to incur high transaction costs to participate in distant markets, where people converge from different locations to either sell or buy foods, inputs, and other products. As discussed previously, these constraints on market access may have negative impacts on food security through several pathways, including agricultural production, prices, incomes, food availability, and food access.

\section{Data and methods}

\subsection{Data}

The data used for the empirical analysis is obtained from the second and third rounds of the Sierra Leone Integrated
Household Survey (SLIHS) conducted by Statistics Sierra Leone in 2011 and 2018. The SLIHS is a repeated crosssectional, nationally representative income and expenditure survey, specifically designed to provide relevant statistics on the living standards of Sierra Leoneans and to guide the formulation of interventions towards poverty reduction in Sierra Leone. While the first round was conducted in 2003/2004, only the second and third rounds of SLIHS are comparable in terms of sampling techniques and questionnaires. A two-stage random sampling design was used in the 2011 and 2018 SLIHS. In the first stage, enumeration areas from 2004 and 2015 censuses, were stratified according to district and locality (rural vs. urban) and sampled using probability proportional to size. Households were then selected in the second stage using simple random sampling (Statistics Sierra Leone, 2014, 2019a).

A salient feature of the 2011 and 2018 SLIHS is that they were administered over 12 months (January-December). The study exploits this aspect of the dataset to analyse the associations between seasonality, nearness to food markets, and food security in Sierra Leone. In addition to household income and consumption expenditure, the SLIHS collected information on agricultural production, health, education, and other social, economic, and demographic characteristics of individuals, households, and communities. Also included in the 2018 SLIHS (but not in earlier rounds) is a food security module, which we utilized in our analysis. The SLIHS covered 6,727 and 6840 households in 2011 and 2018, respectively. However, the final sample for the analyses consists of 13,256 households after combining the various modules from both rounds.

\subsection{Measurement of variables}

\subsubsection{Dietary diversity and food security indicators}

The key to a healthy, high-quality diet for better nutrition is consuming a variety of foods from different groups (Arimond et al., 2011; Thiele \& Weiss, 2003). Dietary diversity is usually measured as the count of food groups or individual food items consumed by a household or an individual over a 24-h or 7-day recall period (Kennedy et al., 2010). However, the household food consumption data from SLIHS 2011 and 2018 were based on daily food diaries, completed over a 5-day interval for one month. Food consumption expenditures were thus aggregated over a 30-day recall period, involving 4-5 visits to each household. Most households are likely to consume from diverse food groups at least once a month. Hence, a dietary diversity indicator based on food groups consumed over extended recall periods, say 30 days, may not only be an overestimate but also a poor predictor of dietary quality or nutritional adequacy 
(Ecker, 2018). Another limitation is that we do not have household-level information on the quantities and prices of food items consumed.

Therefore, we resort to the Simpson diversity index or Berry index to measure dietary diversity based on the shares of food groups in total (purchased and own produced) food expenditure. The household dietary diversity index $(H D D I)$ for household $i$ is constructed as

$H D D I_{i}=1-\sum_{j=1}^{k} \omega_{i j}^{2}$

where $\omega_{\mathrm{ij}}$ is the share of food group $j$ in total food consumption expenditure of household $i$ and $k$ is the number of food groups. Following Anim and Frimpong (2018), we used twelve food groups (i.e. $\mathrm{k}=12$ ), namely: cereals, roots and tubers, chicken, meat, fish, diary, eggs, milk and milk products, fruits, vegetables, pulses, oils and fats, condiments, and beverages and confectionary. The HDDI is bounded between 0 and 1, with 0 representing a situation where household $i$ spends on or consumes from only one food group and 1 where the household devotes equal shares of its food budget to all food groups considered. Thus, while higher values are suggestive of a higher diversity of household food expenditure, lower values are indicative of less diversity in food expenditure, and thus, consumption of more concentrated or highly monotonous diets (Drescher et al., 2007; Thiele \& Weiss, 2003). In analysing the role of markets, HDDI based on purchased foods and own-produced foods are also computed to identify the relative importance of different food sources for household dietary diversity across seasons (Muthini et al., 2020).

Household food (in)security is measured by the coping strategy index (CSI) (Maxwell \& Caldwell, 2008) and household hunger scale (HHS) (Ballard et al., 2011). These household hunger indicators capture the severity and frequency of strategies households adopt in the face of inadequate household food access. For sensitivity checks, we also employed the shares of food (FDSH), and non-staple foods in total food consumption expenditure (NSTASH) as proxy indicators of food consumption patterns. As total household income (which can be proxied by total consumption expenditure) increases, households will reduce the proportion of budget spent on food (Engel's Law), and shift their diets away from starchy staples to nutrient-dense, non-staple foods such as meat, fish, fruits, vegetables, dairy, legumes, and oils (Bennett's Law). To ensure that changes in the dietary diversity indicators are reflective of changes in the nutritional quality of the foods that households consume, all consumption expenditures (and budget shares) are based on real values, which adjust for price movements.

\subsubsection{Seasonality and market access indicators}

We measure seasonality in two ways in the spirit of Chirwa et al. (2012), and Handa and Mlay (2006). First, based on the month of interview, seasonality is captured by eleven monthly dummy variables for each round of SLIHS, with December as the reference category. Second, the study categorizes the months of interview into three farming seasons or trimesters (four-month periods) based on Famine Early Warning Systems Network's (FEWS NET) seasonal calendar of a typical year in Sierra Leone (Pasqualino et al., 2016). Trimester 1 spans February-May and captures the dry, post-harvest, and pre-planting period when there is neither serious food shortage nor food glut. The major agricultural activities occurring within this period are land preparation for rice and marketing of cash crops (mainly cashew, coffee, and palm oil). Trimester 2, which covers June-September, is the growing season as well as the lean period when food insecurity is most acute. It concurs with the wettest season of the year when rainfall conditions are most suitable for land preparations (upland rice), planting (rice, cassava, vegetables, yams, sweet potato, and pepper), weeding (groundnut, maize, and millet) and minor harvest (of maize, millet, cassava, and cashew). Trimester 3 (October-January) is the harvesting and marketing period, traversing the rainy and dry seasons. Most households have increased food supply and purchasing power during this period, as it coincides with the harvest and marketing of several food crops and cash crops.

As typical of other West African countries, markets in Sierra Leone operate daily (mostly in urban areas) and periodically on at least one fixed day each week (especially in smaller towns/rural areas). They are mostly open-air markets located at the commercial hub of villages, towns, and cities. Market participants, mostly women, regularly converge at these market centres - with official market day(s) being the busiest day(s) - to purchase and/or sell varieties of locally produced or imported foodstuffs, and other commodities. Physical market infrastructures are commonly characterized by wooden or concrete tables under pavilions roofed with corrugated iron sheets or raffia palm leaves to serve as trading stalls. Improved booths, stores, and stalls can be found in larger, central markets in urban areas. As documented in Bonuedi (2021), and Headey et al. (2019) the local supply of rice, maize, cassava, fresh fruits and vegetables, fish, and other important foodstuffs in these markets may be affected by agricultural seasonality. However, their market availability is considerably augmented by supply from neighbouring towns, regions and countries, albeit at higher prices due to transportation and other trade costs.

Market access has been measured in different ways, of which distance or time to a nearest market centre or nearest all-weather or paved road are most often used (Headey 
et al., 2019; Usman \& Callo-Concha, 2021). In this study, based on the available data, we measured proximity to food markets by the time (minutes) it takes a household to reach the nearest food market by the most frequent means. This market access indicator was reported as categorical (i.e. six 15-min categories), rather than continuous. Hence, a household is considered to be close to a food market (or have better access) if it reaches food markets within one hour. With foot/walking being the most frequent mode of reaching markets in Sierra Leone, the 60-min cut-off point is equivalent to a walking distance of $5 \mathrm{~km}$. Similar proximity thresholds have been used in the literature (Abay \& Hirvonen, 2017).

As a robustness check, we employ time to reach the nearest all-season road as an alternative indicator of market access (Usman \& Callo-Concha, 2021; WFP, 2017). Measured in the same manner as travel time to food markets, a household is deemed to have better access if it reaches an all-weather road within an hour. Although travel time to food markets is a more direct measure of market access than proximity to an all-season road, the latter bestows important beneficial effects on food security, beyond cheaper transport to and from agricultural markets. The other important benefits of nearness to roads include improved access to schools, and health facilities, which strongly affect the utilization dimension of food security (Jacoby, 2000; Jacoby $\&$ Minten, 2009). A major drawback of these market access indicators is that they only measure proximity to markets, and do not adequately capture nutritional dimensions of market quality (e.g. diversity, availability and affordability of foods sold in the market). As Headey et al. (2019) demonstrated, capturing these nutrition-relevant market characteristics requires an unusually extensive market survey (Headey et al., 2019). This information is unavailable in the SLIHS dataset, hence our adoption of proximity to food markets and roads as the most suitable market access indicators.

\subsubsection{Control variables}

Several control variables are also included in the analysis to account for the influence of other drivers of dietary diversity and food security. Household socio-economic characteristics are captured by the head's age, gender, marital status and education status, livelihoods (sector of occupation), an assetbased wealth index, and household ownership of livestock and agricultural land. Household head's religion is used to control for the influence of beliefs and practices on food consumption. Household demographic structure is captured by the number of members aged $0-15,15-64$, and over 64 . The nearness of drinking water supply and health clinic is also included to control for community characteristics. Lastly, district and survey fixed effects are also included to deal with omitted variable bias due to unobserved heterogeneity.

\subsubsection{Pathway variables}

Premised on theoretical considerations, we hypothesize market participation, non-farm income-generating avenues, and consumption credits as the potential pathways through which market access may affect food security and dietary outcomes across seasons. Market participation is measured using the crop commercialization index and a binary indicator of whether or previous year's farm produce was sold at the farmgate. Following von Braun and Kennedy (1995) and Carletto et al. (2017) we compute the crop commercialization index as the share of the total value of farm output sold. Due to data limitations, only the value of food crops and cash crops produced by the household during the last 12-months preceding the survey are considered in measuring the index. Similarly, due to inconsistencies as well as missing information on prices for identical crops and units for some households, the average sales prices reported by the sampled households are used to value farm output. Access to off-farm income-creating opportunities is proxied by an indicator of whether or not the household operates a non-farm enterprise. Lastly, credit access is captured by an indicator of whether or not the household obtains credit for consumption purposes. Table 7 fully describes the measurement of all variables employed in the study.

\subsection{Model specification and estimation strategy}

The analysis is carried out in two sections. In the first section, we estimate a food consumption model that relates different indicators of household dietary diversity and food security to a set of seasonal variables and control variables. The basic specification for food security-seasonality model is given as:

$Y_{i t}=\alpha+\beta S_{i t}+\delta X_{i t}+\gamma D_{i}+\psi T+\varepsilon_{i t}$

where $Y_{i}$ is the dietary diversity or food security indicator of household $i$ surveyed at time $t . S$ is a vector of seasonal dummies, capturing the month or farming season within which the interview occurred. $X$ is a vector of household socio-economic and demographic characteristics. $D$ is a set of district fixed effects; $T$ is the linear time trend, capturing general, unobserved non-seasonal differences in household food and nutrition security between the survey years 2011 and 2018, and $\varepsilon$ is the error term. The scalar $\beta$ contains the parameters of interest, capturing the effects of different seasons on household food and nutrition security. We used the Wald $F$ test to test for the joint significance of all seasonality coefficients. 
Table 1 Summary statistics

\begin{tabular}{|c|c|c|c|c|c|c|c|}
\hline & \multicolumn{2}{|l|}{2011} & \multicolumn{2}{|l|}{2018} & \multicolumn{2}{|l|}{ Pooled } & \multirow[b]{2}{*}{ Diff } \\
\hline & Mean & SD & Mean & SD & Mean & SD & \\
\hline \multicolumn{8}{|l|}{ Dietary diversity \& food security indicators } \\
\hline HH dietary diversity index, HDDI $(0-1)$ & 0.75 & 0.10 & 0.86 & 0.06 & 0.81 & 0.10 & $0.11^{* * *}$ \\
\hline Purchased HDDI & 0.73 & 0.11 & 0.85 & 0.07 & 0.79 & 0.11 & $0.12^{* * *}$ \\
\hline Own food HDDI & 0.72 & 0.34 & 0.76 & 0.31 & 0.74 & 0.32 & $0.03^{* * *}$ \\
\hline Share of food in HH consumption exp & 0.63 & 0.18 & 0.46 & 0.16 & 0.54 & 0.19 & $-0.17^{* * *}$ \\
\hline Share of staple foods exp. in the food budget & 0.42 & 0.15 & 0.30 & 0.11 & 0.36 & 0.15 & $-0.12^{* * *}$ \\
\hline Share of non-staple foods exp. in food budget & 0.45 & 0.12 & 0.48 & 0.14 & 0.46 & 0.13 & $0.03^{* * *}$ \\
\hline Coping strategy index & & & 7.98 & 8.33 & 7.98 & 8.33 & \\
\hline Household hunger scale $(0-6)$ & & & 1.17 & 1.13 & 1.17 & 1.13 & \\
\hline \multicolumn{8}{|l|}{ Seasonality \& market access } \\
\hline Post-harvest season (February-May) (1/0) & 0.35 & 0.48 & 0.33 & 0.47 & 0.34 & 0.48 & $-0.02^{* *}$ \\
\hline Lean \& growing season (June-September) (1/0) & 0.35 & 0.48 & 0.33 & 0.47 & 0.34 & 0.47 & $-0.02^{*}$ \\
\hline Harvest season (October-January) (1/0) & 0.30 & 0.46 & 0.33 & 0.47 & 0.32 & 0.46 & $0.04^{* * *}$ \\
\hline Close to food market ( $=1$ if time is $\leq 60 \mathrm{~min}$ ) & 0.68 & 0.47 & 0.79 & 0.41 & 0.73 & 0.44 & $0.11^{* * *}$ \\
\hline Lean \& close to food market $(1 / 0)$ & 0.29 & 0.45 & 0.34 & 0.47 & 0.31 & 0.46 & $0.06^{* * *}$ \\
\hline Lean season $\&$ far from food market $(1 / 0)$ & 0.16 & 0.36 & 0.08 & 0.27 & 0.12 & 0.32 & $-0.08^{* * *}$ \\
\hline Non-lean season \& close to food market (1/0) & 0.39 & 0.49 & 0.45 & 0.50 & 0.42 & 0.49 & $0.06^{* * *}$ \\
\hline Non-lean season \& far from food market $(1 / 0)$ & 0.17 & 0.38 & 0.13 & 0.34 & 0.15 & 0.36 & $-0.04^{* * *}$ \\
\hline \multicolumn{8}{|l|}{ Control variables } \\
\hline HHD is male $(1 / 0)$ & 0.74 & 0.44 & 0.75 & 0.43 & 0.75 & 0.44 & 0.001 \\
\hline Age of HHD (years) & 45.59 & 14.19 & 45.91 & 14.26 & 45.75 & 14.22 & 0.33 \\
\hline HHD in monogamous marriage $(1 / 0)$ & 0.63 & 0.48 & 0.61 & 0.49 & 0.62 & 0.49 & -0.02 \\
\hline HHD in polygamous marriage $(1 / 0)$ & 0.16 & 0.37 & 0.16 & 0.37 & 0.16 & 0.37 & 0.00 \\
\hline HHD is divorced, separated or widowed (1/0) & 0.15 & 0.36 & 0.17 & 0.37 & 0.16 & 0.37 & $0.02^{* *}$ \\
\hline HHD has never married $(1 / 0)$ & 0.05 & 0.22 & & & 0.05 & 0.22 & \\
\hline No. of HHM aged $0-14$ years & 2.20 & 1.71 & 2.31 & 1.76 & 2.26 & 1.74 & $0.11^{* * *}$ \\
\hline No. of HHM aged 15-64 years & 3.17 & 1.69 & 3.25 & 1.92 & 3.21 & 1.82 & $0.08^{*}$ \\
\hline No. of HHM aged over 64 years & 0.23 & 0.50 & 0.25 & 0.50 & 0.24 & 0.50 & 0.02 \\
\hline HHD is waged/salaried employee (1/0) & 0.15 & 0.36 & 0.25 & 0.44 & 0.20 & 0.40 & $0.11^{* * *}$ \\
\hline HHD is employed in agriculture (1/0) & 0.58 & 0.49 & 0.42 & 0.49 & 0.50 & 0.50 & $-0.16^{* * *}$ \\
\hline HHD is employed in non-agriculture $(1 / 0)$ & 0.24 & 0.43 & 0.18 & 0.39 & 0.21 & 0.41 & $-0.06^{* * *}$ \\
\hline HH owns any livestock (1/0) & 0.39 & 0.49 & 0.50 & 0.50 & 0.44 & 0.50 & $0.11^{* * *}$ \\
\hline HH owns any agricultural land (1/0) & 0.55 & 0.50 & 0.49 & 0.50 & 0.52 & 0.50 & $-0.06^{* * *}$ \\
\hline HH wealth index $(0-100)$ & 52.13 & 11.40 & 56.97 & 13.70 & 54.55 & 12.83 & $4.84^{* * *}$ \\
\hline HHD is Christian (1/0) & 0.23 & 0.42 & 0.23 & 0.42 & 0.23 & 0.42 & -0.01 \\
\hline HHD is Muslim (1/0) & 0.76 & 0.43 & 0.77 & 0.42 & 0.76 & 0.43 & 0.01 \\
\hline HHD has other or no religion $(1 / 0)$ & 0.01 & 0.09 & 0.00 & 0.06 & 0.01 & 0.08 & $-0.00^{* * *}$ \\
\hline HHD has no education $(1 / 0)$ & 0.67 & 0.47 & 0.52 & 0.50 & 0.60 & 0.49 & $-0.14^{* * *}$ \\
\hline HHD has primary education (1/0) & 0.08 & 0.27 & 0.11 & 0.32 & 0.10 & 0.30 & $0.04^{* * *}$ \\
\hline HHD has secondary education (1/0) & 0.18 & 0.38 & 0.24 & 0.43 & 0.21 & 0.41 & $0.06^{* * *}$ \\
\hline HHD has post-secondary education (1/0) & 0.06 & 0.23 & 0.09 & 0.28 & 0.07 & 0.26 & $0.03^{* * *}$ \\
\hline HHD has college degree $(1 / 0)$ & 0.02 & 0.14 & 0.04 & 0.19 & 0.03 & 0.17 & $0.02^{* * *}$ \\
\hline Time to drinking water source $\leq 30 \mathrm{~min}(1 / 0)$ & 0.88 & 0.32 & 0.86 & 0.35 & 0.87 & 0.33 & $-0.02^{* * *}$ \\
\hline Time to drinking water source $31-60 \mathrm{~min}(1 / 0)$ & 0.09 & 0.29 & 0.11 & 0.31 & 0.10 & 0.30 & $0.01^{*}$ \\
\hline Time to drinking water source $>60 \min (1 / 0)$ & 0.02 & 0.15 & 0.03 & 0.18 & 0.03 & 0.17 & $0.01^{* *}$ \\
\hline Time to health clinic $\leq 30 \min (1 / 0)$ & 0.42 & 0.49 & 0.57 & 0.50 & 0.50 & 0.50 & $0.16^{* * *}$ \\
\hline Time to health clinic $31-60 \min (1 / 0)$ & 0.34 & 0.47 & 0.23 & 0.42 & 0.28 & 0.45 & $-0.11^{* * *}$ \\
\hline Time to health clinic > $60 \min (1 / 0)$ & 0.25 & 0.43 & 0.20 & 0.40 & 0.22 & 0.42 & $-0.05^{* * *}$ \\
\hline
\end{tabular}


Table 1 (continued)

\begin{tabular}{|c|c|c|c|c|c|c|c|}
\hline & \multicolumn{2}{|l|}{2011} & \multicolumn{2}{|l|}{2018} & \multicolumn{2}{|c|}{ Pooled } & \multirow[b]{2}{*}{ Diff } \\
\hline & Mean & SD & Mean & SD & Mean & SD & \\
\hline \multicolumn{8}{|l|}{ Pathway variables } \\
\hline Share of gross value of farm output sold $(0-1)$ & 0.15 & 0.26 & 0.61 & 0.28 & 0.33 & 0.35 & $0.46^{* * *}$ \\
\hline Sold crops to farm gate buyer $(1 / 0)$ & 0.27 & 0.44 & 0.18 & 0.39 & 0.22 & 0.42 & $-0.08^{* * *}$ \\
\hline HH operates a non-farm enterprise $(1 / 0)$ & 0.18 & 0.38 & 0.51 & 0.50 & 0.34 & 0.48 & $0.33^{* * *}$ \\
\hline $\mathrm{HH}$ accessed credit for consumer goods $(1 / 0)$ & 0.25 & 0.43 & 0.34 & 0.47 & 0.31 & 0.46 & $0.09^{* * *}$ \\
\hline Observations, $N$ & 6628 & & 6628 & & 13256 & & \\
\hline
\end{tabular}

$1 / 0$ is a binary indicator and equals 1 if yes, and 0 otherwise. SD denotes standard deviation

Source: Own computation based on SLIHS 2011 \& 2018

$H H$ stands for household, $H H D$ denotes household head and HHM refers to household member

$* p<0.05 ; * * p<0.01 ; * * * p<0.001$

In the second part, we examined the role of market access as a potential policy instrument in addressing seasonal food insecurity in Sierra Leone. The formal approach to quantify the relative seasonal effects of market access on food security is to estimate a food security model with seasonality and market access measures and their interaction term (along with other covariates) as explanatory variables. However, given the data at hand, including the entire 11 monthly (seasonal) dummies along with five separate categories of time to food markets and their interaction terms will result in over-parameterization. This will churn out a bunch of regression coefficients that may have low statistical power and be difficult to interpret. To overcome these problems, while accounting for the non-linear relationship between market access and household diets and food security across seasons, we take a more straightforward approach, following Abay and Hirvonen (2017), by dividing seasonality and market access into two groups each. We categorize the month of the interview into the lean season $(L S)$ and non-lean (sufficient) season $(N L)$ and market access as close to markets $(C M)$ and far from markets $(F M)$. We then estimate the following model:

$$
\begin{aligned}
Y_{i t}= & \alpha+\beta_{1} L S C M_{i t}+\beta_{2} N L C M_{i t}+\beta_{3} N L F M_{i t} \\
& +\delta X_{i t}+\gamma D_{i}+\psi T+\varepsilon_{i t}
\end{aligned}
$$

where $L S C M, N L C M$, and NLFM are seasonality and market access interaction terms. $L S C M$ equals 1 if the season of interview is lean (that is, June - September, the period of most acute food deprivation), and the household is located close (or within 60 min distance) to a food market and zero otherwise. NLCM takes the value of 1 if the season is nonlean (that is, harvest and post-harvest months when relative food sufficiency exists, October - May), and the household is located close to a food market and zero otherwise. NLFM equals 1 if the season is non-lean, and the household is not close (more than $60 \mathrm{~min}$ distance) to a food market and zero otherwise. Hence, the reference category covers households interviewed in the non-lean season and are located far from a food market. As robustness check, similar interaction terms are employed when proximity to an all-season road is used as the alternative measure for market access. All other variables remain as previously defined. The $\beta$ coefficients capture the seasonal effects of market access on household diets and food security relative to the reference category.

Considering seasonal variabilities and location of markets to be mostly exogenous to household consumption decisions, the ordinary least squares (OLS) technique is utilized to estimate the parameters in the models specified above. Concerns for heteroscedasticity, which typically affects the analysis of cross-section data, are addressed using robust standard errors. The possibility that households that are concerned about their food security and nutritional wellbeing may relocate to areas with better market access raises concern about the endogeneity of the market access variable. However, this concern is allayed by the fact that widespread poor transport infrastructure imposes high transportation costs and creates relocation difficulties for households seeking better dietary and food security outcomes. Also, private land markets are absent in Sierra Leone, as lands are mostly acquired based on informed consent either through family inheritance or by community allocation (Ochiai, 2017). This makes private land acquisition highly difficult. As Hirvonen et al. (2017) argued, the absence of private land markets suggests that households seeking better dietary diversity would have considerable difficulties doing so by relocating their families or farms nearer to the markets.

\section{Results and discussion}

\subsection{Descriptive statistics}

Table 1 presents the summary statistics of the variables employed in the analysis. The results of the test of differencebetween-means are shown in the last column. The descriptive 
Table 2 Effects of monthly seasonality on household dietary diversity and food security

\begin{tabular}{|c|c|c|c|c|c|}
\hline & \multicolumn{2}{|c|}{ Dietary diversity } & \multicolumn{3}{|c|}{ Food security } \\
\hline & (1) & (2) & (4) & (5) & (6) \\
\hline & HDDI & NSTASH & FDSH & CSI & HHS \\
\hline \multirow[t]{2}{*}{ January } & $0.019^{* * * *}$ & -0.005 & $-0.064^{* * *}$ & $0.446^{* * *}$ & $0.357^{* * * *}$ \\
\hline & $(0.003)$ & $(0.006)$ & $(0.008)$ & $(0.084)$ & $(0.066)$ \\
\hline \multirow[t]{2}{*}{ February } & $0.014^{* * * *}$ & $-0.020^{* * *}$ & $-0.032^{* * *}$ & $0.388^{* * *}$ & $0.260^{* * * *}$ \\
\hline & $(0.003)$ & $(0.006)$ & $(0.007)$ & $(0.078)$ & $(0.064)$ \\
\hline \multirow[t]{2}{*}{ March } & 0.004 & $-0.015^{* *}$ & -0.009 & $0.310^{* * * *}$ & $0.133^{* *}$ \\
\hline & $(0.003)$ & $(0.006)$ & $(0.007)$ & $(0.076)$ & $(0.061)$ \\
\hline \multirow[t]{2}{*}{ April } & $-0.006^{*}$ & $-0.026^{* * *}$ & 0.002 & $0.143^{*}$ & 0.090 \\
\hline & $(0.003)$ & $(0.006)$ & $(0.007)$ & $(0.078)$ & $(0.058)$ \\
\hline \multirow[t]{2}{*}{ May } & $-0.011^{* * * *}$ & $-0.029^{* * *}$ & 0.005 & 0.125 & $0.134^{* *}$ \\
\hline & $(0.003)$ & $(0.006)$ & $(0.007)$ & $(0.079)$ & $(0.061)$ \\
\hline \multirow[t]{2}{*}{ June } & $-0.017^{* * * *}$ & $-0.036^{* * *}$ & $0.019^{* * *}$ & $0.203^{* * *}$ & $0.142^{* *}$ \\
\hline & $(0.003)$ & $(0.006)$ & $(0.007)$ & $(0.077)$ & $(0.060)$ \\
\hline \multirow[t]{2}{*}{ July } & -0.003 & $-0.046^{* * *}$ & $0.016^{* * *}$ & $0.159^{* *}$ & $0.146^{* *}$ \\
\hline & $(0.003)$ & $(0.006)$ & $(0.007)$ & $(0.078)$ & $(0.059)$ \\
\hline \multirow[t]{2}{*}{ August } & $-0.009^{* * * *}$ & $-0.028^{* * *}$ & $0.033^{* * *}$ & $0.291^{* * * *}$ & $0.227^{* * *}$ \\
\hline & $(0.003)$ & $(0.006)$ & $(0.007)$ & $(0.075)$ & $(0.058)$ \\
\hline \multirow[t]{2}{*}{ September } & $-0.013^{* * * *}$ & $-0.041^{* * *}$ & $0.044^{* * *}$ & 0.098 & -0.047 \\
\hline & $(0.003)$ & $(0.006)$ & $(0.007)$ & $(0.079)$ & $(0.058)$ \\
\hline \multirow[t]{2}{*}{ October } & $-0.012^{* * * *}$ & $-0.033^{* * *}$ & $0.029^{* * *}$ & $0.271^{* * * *}$ & $0.181^{* * *}$ \\
\hline & $(0.003)$ & $(0.006)$ & $(0.007)$ & $(0.074)$ & $(0.057)$ \\
\hline \multirow[t]{2}{*}{ November } & -0.005 & $-0.011^{*}$ & 0.005 & $-0.159^{* *}$ & -0.020 \\
\hline & $(0.003)$ & $(0.006)$ & $(0.008)$ & $(0.077)$ & $(0.059)$ \\
\hline \multirow[t]{2}{*}{ Constant } & $0.767^{* * * *}$ & $0.394^{* * *}$ & $0.799^{* * *}$ & $2.118^{* * *}$ & $1.582^{* * * *}$ \\
\hline & $(0.011)$ & $(0.018)$ & $(0.021)$ & $(0.397)$ & $(0.316)$ \\
\hline Controls & Yes & Yes & Yes & Yes & Yes \\
\hline District fixed effects & Yes & Yes & Yes & Yes & Yes \\
\hline Year fixed effects & Yes & Yes & Yes & $\mathrm{n} / \mathrm{a}$ & $\mathrm{n} / \mathrm{a}$ \\
\hline$N$ & 13122 & 13122 & 13122 & 6624 & 6624 \\
\hline$R_{a d j}^{2}$ & 0.46 & 0.136 & 0.37 & 0.300 & 0.194 \\
\hline F-test for months & 26.30 & 12.69 & 38.85 & 9.30 & 6.86 \\
\hline $\mathrm{F}(p$-value $)$ & $(0.00)$ & $(0.00)$ & $(0.00)$ & $(0.00)$ & $(0.00)$ \\
\hline
\end{tabular}

OLS estimation. HHDI is the Berry index of household dietary diversity. FDSH is the share of food expenditure in total consumption expenditure. NSTASH is the share of expenditure on non-staple foods in the household food budget. CSI is the (log of) coping strategy index, and HHS is the household hunger scale. The omitted category is December. The control variables are provided in Table 1. Robust standard errors in parentheses

$p<0.10 ;{ }^{* *} p<0.05 ;{ }^{* * *} p<0.01$

results show that, on average, the HDDI increased from 0.75 in 2011 to 0.86 in 2018. This suggests that the diets of Sierra Leonean households have significantly improved, in terms of diversity, over the years. As a reflection of increased affluence, the share of food expenditure significantly declined from 0.63 to 0.46 over this period. In particular, the share of staple foods in household food expenditure declined, whereas that of non-staple foods significantly increased between 2011 and 2018, showing the growing importance of nutritious, non-staple foods in household diets in Sierra Leone. The distribution of households across seasons was quite uniform in both waves of SLIHS. Market access has also remarkably improved, with $79 \%$ of households reaching the nearest food market within an hour in 2018, relative to $68 \%$ in 2011 . As shown Table 8 , there are also suggest significant variations in these across seasons.

Most households were male-headed, with a mean age of about 46 years. Most household heads were monogamously married. There was no significant change in these characteristics during 2011-2018, except for a $2 \%$ increase in the 
Table 3 Effects of farming seasons on household dietary diversity and food security

\begin{tabular}{|c|c|c|c|c|c|}
\hline & \multicolumn{2}{|c|}{ Dietary diversity } & \multirow[b]{2}{*}{ (3) } & \multicolumn{2}{|c|}{ Food security } \\
\hline & (1) & (2) & & (4) & $(5)$ \\
\hline & HDDI & NSTASH & FDSH & CSI & HHS \\
\hline \multicolumn{6}{|l|}{ Panel A: National } \\
\hline Post-harvest season & $\begin{array}{l}-0.003^{*} \\
(0.002)\end{array}$ & $\begin{array}{l}-0.010^{* * *} \\
(0.003)\end{array}$ & $\begin{array}{l}-0.000 \\
(0.003)\end{array}$ & $\begin{array}{l}0.106^{* * *} \\
(0.040)\end{array}$ & $\begin{array}{l}0.043 \\
(0.032)\end{array}$ \\
\hline Growing/lean season & $\begin{array}{l}-0.012^{* * *} \\
(0.002)\end{array}$ & $\begin{array}{l}-0.026^{* * *} \\
(0.003)\end{array}$ & $\begin{array}{l}0.039^{* * *} \\
(0.003)\end{array}$ & $\begin{array}{l}0.023 \\
(0.040)\end{array}$ & $\begin{array}{l}-0.026 \\
(0.031)\end{array}$ \\
\hline Constant & $\begin{array}{l}0.741^{\text {*** }} \\
(0.003)\end{array}$ & $\begin{array}{l}0.549^{* * *} \\
(0.005)\end{array}$ & $\begin{array}{l}0.621^{* * * *} \\
(0.006)\end{array}$ & $\begin{array}{l}1.680^{* * *} \\
(0.095)\end{array}$ & $\begin{array}{l}1.273^{* * *} \\
(0.084)\end{array}$ \\
\hline Controls & Yes & Yes & yes & yes & Yes \\
\hline District fixed effects & Yes & Yes & yes & yes & Yes \\
\hline Year fixed effects & Yes & Yes & yes & $\mathrm{n} / \mathrm{a}$ & $\mathrm{n} / \mathrm{a}$ \\
\hline$N$ & 13,256 & 13,256 & 13,256 & 6628 & 6628 \\
\hline$R_{a d j}^{2}$ & 0.415 & 0.073 & 0.300 & 0.209 & 0.137 \\
\hline F-test for seasons & 32.22 & 42.65 & 95.61 & 4.03 & 2.33 \\
\hline $\mathrm{F}(p$-value $)$ & $(0.00)$ & $(0.00)$ & $(0.00)$ & $(0.018)$ & $(0.097)$ \\
\hline \multicolumn{6}{|l|}{ Panel B: Rural } \\
\hline Post-harvest season & $\begin{array}{l}0.001 \\
(0.002)\end{array}$ & $\begin{array}{l}-0.008^{* *} \\
(0.004)\end{array}$ & $\begin{array}{l}0.014^{* * *} \\
(0.005)\end{array}$ & $\begin{array}{l}0.026 \\
(0.049)\end{array}$ & $\begin{array}{l}0.032 \\
(0.046)\end{array}$ \\
\hline Growing/lean season & $\begin{array}{l}-0.009^{* * *} \\
(0.002)\end{array}$ & $\begin{array}{l}-0.036^{\text {**** }} \\
(0.004)\end{array}$ & $\begin{array}{l}0.056^{* * *} \\
(0.005)\end{array}$ & $\begin{array}{l}0.149^{* * *} \\
(0.049)\end{array}$ & $\begin{array}{l}0.044 \\
(0.045)\end{array}$ \\
\hline Constant & $\begin{array}{l}0.732^{* * *} \\
(0.003)\end{array}$ & $\begin{array}{l}0.549^{* * *} \\
(0.006)\end{array}$ & $\begin{array}{l}0.622^{* * *} \\
(0.008)\end{array}$ & $\begin{array}{l}1.617^{* * *} \\
(0.118)\end{array}$ & $\begin{array}{l}1.129^{* * *} \\
(0.102)\end{array}$ \\
\hline Controls & Yes & Yes & yes & yes & Yes \\
\hline District fixed effects & Yes & Yes & yes & yes & Yes \\
\hline Year fixed effects & Yes & Yes & yes & $\mathrm{n} / \mathrm{a}$ & $\mathrm{n} / \mathrm{a}$ \\
\hline$N$ & 7591 & 7591 & 7591 & 3337 & 3337 \\
\hline$R_{a d j}^{2}$ & 0.397 & 0.105 & 0.347 & 0.188 & 0.116 \\
\hline F-test for seasons & 9.86 & 63.19 & 82.84 & 5.12 & 0.53 \\
\hline $\mathrm{F}(p$-value $)$ & $(0.00)$ & $(0.00)$ & $(0.00)$ & $(0.001)$ & $(0.589)$ \\
\hline \multicolumn{6}{|l|}{ Panel C: Urban } \\
\hline Post-harvest season & $\begin{array}{l}-0.001 \\
(0.002)\end{array}$ & $\begin{array}{l}-0.012^{* *} \\
(0.005)\end{array}$ & $\begin{array}{l}-0.034^{* * *} \\
(0.005)\end{array}$ & $\begin{array}{l}0.200^{* * * *} \\
(0.065)\end{array}$ & $\begin{array}{l}0.038 \\
(0.046)\end{array}$ \\
\hline Growing/lean season & $\begin{array}{l}-0.004^{* *} \\
(0.002)\end{array}$ & $\begin{array}{l}-0.006 \\
(0.005)\end{array}$ & $\begin{array}{l}-0.003 \\
(0.005)\end{array}$ & $\begin{array}{l}0.020 \\
(0.061)\end{array}$ & $\begin{array}{l}-0.047 \\
(0.043)\end{array}$ \\
\hline Constant & $\begin{array}{l}0.761^{* * *} \\
(0.004)\end{array}$ & $\begin{array}{l}0.558^{* * *} \\
(0.009)\end{array}$ & $\begin{array}{l}0.588^{* * *} \\
(0.011)\end{array}$ & $\begin{array}{l}1.754^{* * * *} \\
(0.156)\end{array}$ & $\begin{array}{l}1.481^{* * *} \\
(0.143)\end{array}$ \\
\hline Controls & Yes & Yes & yes & yes & Yes \\
\hline District fixed effects & Yes & Yes & yes & yes & Yes \\
\hline Year fixed effects & Yes & Yes & yes & $\mathrm{n} / \mathrm{a}$ & $\mathrm{n} / \mathrm{a}$ \\
\hline$N$ & 5665 & 5665 & 5665 & 3291 & 3291 \\
\hline$R_{a d j}^{2}$ & 0.352 & 0.044 & 0.153 & 0.157 & 0.132 \\
\hline F-test for seasons & 2.62 & 3.25 & 28.63 & 6.08 & 1.94 \\
\hline $\mathrm{F}(p$-value $)$ & $(0.073)$ & $(0.039)$ & $(0.000)$ & $(0.002)$ & $(0.144)$ \\
\hline
\end{tabular}

OLS estimation. See notes beneath Table 2. Robust standard errors in parentheses ${ }^{*} p<0.10,{ }^{* *} p<0.05,{ }^{* * *}$ $p<0.01$. The reference category is the harvest season (October-January) 
proportion of divorced, separated, or widowed household heads. Islam remained the dominant religion of household heads. Although it remains unacceptably low, literacy rates improved in 2018, with about $15 \%$ decline in the share of household heads who had no formal education from $67 \%$ in 2011. This is seen in the significant increments in the proportions of households attaining primary and secondary education. Attainment of post-secondary and college education remains undesirably low.

In terms of livelihoods, agriculture is the primary source of employment for household heads, although its importance declined from 58\% in 2011 to $42 \%$ in 2018 . On the contrary, the percentage of household heads engaged in waged or salaried employment in public or private sectors has significantly increased from 15 to $25 \%$ over the same period, signifying nascent transformations in the overall structure of the Sierra Leonean economy. While ownership of agricultural land declined, ownership of livestock and possession of some durable assets (generally, of medium quality) improved during the study period. With regards to access to basic social services, majority of households can reach a drinking water source within half an hour, although the proportion has fallen by $2 \%$ from $88 \%$ in 2011 . Albeit improving, access to health care leaves much to be desired, as less than two-thirds of the surveyed households reported reaching the nearest health clinic within $30 \mathrm{~min}$ by the most frequent means of transportation.

Finally, the descriptive results show significant increase in commercialization or market participation, measured in terms of the share of the value of farm output sold and whether the farm output was sold at the farmgate or not. The proportion of households operating a non-farm enterprise as well as those who accessed consumer credit also improved significantly over the period. These intermediary variables are further examined to identify the potential pathways through which market access contributes to overcoming seasonal fluctuations in household dietary diversity and food security.

\subsection{The effects of seasonality on dietary diversity and food security}

Reported in Tables 2 and 3 are the regression results from the estimation of Eq. (1) with seasonality measured by monthly dummies and farming seasons respectively. These results demonstrate the extent to which seasonality affects household dietary diversity and food security in Sierra Leone, after controlling for the influence of several factors. The results of Wald tests for the joint significance of the seasonal variables are presented below both tables. As evidenced by the test results in Table 2, the null hypothesis that all seasonal dummies are simultaneously zero is rejected at 1 percent level in all models. This suggests that seasonality exerts significant variations in household dietary diversity and food security in Sierra Leone.

By and large, we observe that closeness to market (in Table 4) or better road access (Table 5) improves both dietary diversity and food security in the lean season as well as non-lean season. Model 1 shows that, in the lean season, the HDDI is 0.01 units (Panel A) higher for households with better market (and road) access than distant households. These results are also true for both rural and urban households (Panels B and C), although the effect is larger and stronger for urban households, reflecting their relatively better connectivity to market centres than rural dwellers. Overall, these results suggests that households dwelling near food markets (or roads) consume more varied diets during the lean season than households residing farther away from food markets during the same season. Albeit small, the coefficients are significant at the conventional error levels, providing evidence that enhancing access to (food) markets can contribute significantly to reducing seasonal hunger and its associated adverse dietary adjustments. ${ }^{1}$

The estimated parameters of models 1-2 in Table 2 show that household diets were significantly better or more diverse in January and February compared to December. This may be most probably due to improved food availability from harvest and New Year festivities. In terms of magnitude, the results show that HDDI was 0.019 units (model 1) significantly higher in January than in December, all other things being equal. Similarly, it was 0.014 units (model 1) higher in February than in December, albeit it declined from its level in January. From thence, food diversity declined throughout the rest of year (relative to December) as the lean season approaches. June appears to be the worst, with 0.017 units (model 1) decline HDDI. As shown in model 2, the general decline in dietary quality is reflected in households cutting back the share of food expenditure on micronutrient-rich, non-staple foods (such as fish, meat, dairy, fruits, and vegetables) in months other than December. Although it remains relatively low compared to December, the negative effects

\footnotetext{
1 Abay and Hirvonen (2016) reported that children located in Ethiopian villages with better market access enjoy more diverse, consuming 0.73 food groups more during the lean season, and 0.71 additional food groups during the sufficient/non-lean season (compared children residing farther away from food markets during the lean season). In the case of Malawi, Koppmair et al. (2016) reported that one additional hour of walking time to district markets lowers household, maternal and children's dietary diversity by 0.207 -0.265 food groups. In their cross-country study (covering Indonesia, Ethiopia, Kenya and Malawi), Sibhatu et al. (2015) also found that household dietary diversity improves by 0.001 food groups for every $1 \mathrm{~km}$ reduction in market distance. While these effect sizes may seem small, the role of markets in improving nutrition remains robust across various studies and improving market access for subsistence farms seems to be a more promising developing strategy (Sibhatu \& Qaim, 2018).
} 
Table 4 Interactive effects of market access and seasonality on household dietary diversity and food security

\begin{tabular}{|c|c|c|c|c|c|c|c|}
\hline & \multicolumn{2}{|c|}{ Dietary diversity } & \multicolumn{2}{|c|}{ Dietary diversity by source } & \multicolumn{3}{|c|}{ Food security } \\
\hline & (1) & $(2)$ & (3) & (4) & $(5)$ & (6) & (7) \\
\hline & HDDI & NSTASH & Purchased HDDI & Own food HDDI & FDSH & CSI & HHS \\
\hline \multicolumn{8}{|c|}{ Panel A: National } \\
\hline$L S C M$ & $\begin{array}{l}0.010^{* * *} \\
(0.003)\end{array}$ & $\begin{array}{l}0.024^{* * *} \\
(0.004)\end{array}$ & $\begin{array}{l}0.022^{* * *} \\
(0.003)\end{array}$ & $\begin{array}{l}-0.007 \\
(0.011)\end{array}$ & $\begin{array}{l}-0.007 \\
(0.005)\end{array}$ & $\begin{array}{l}-0.378^{* * *} \\
(0.056)\end{array}$ & $\begin{array}{l}-0.163^{\text {*** }} \\
(0.058)\end{array}$ \\
\hline$N L C M$ & $\begin{array}{l}0.023^{\text {**** }} \\
(0.003)\end{array}$ & $\begin{array}{l}0.040^{\text {**** }} \\
(0.004)\end{array}$ & $\begin{array}{l}0.045^{* * *} \\
(0.003)\end{array}$ & $\begin{array}{l}-0.016 \\
(0.010)\end{array}$ & $\begin{array}{l}-0.036^{* * *} \\
(0.005)\end{array}$ & $\begin{array}{l}-0.264^{* * *} \\
(0.053)\end{array}$ & $\begin{array}{l}-0.112^{* *} \\
(0.056)\end{array}$ \\
\hline$N L F M$ & $\begin{array}{l}0.013^{\text {**** }} \\
(0.003)\end{array}$ & $\begin{array}{l}0.028^{* * *} \\
(0.004)\end{array}$ & $\begin{array}{l}0.040^{* * *} \\
(0.004)\end{array}$ & $\begin{array}{l}-0.034^{* * *} \\
(0.011)\end{array}$ & $\begin{array}{l}-0.045^{* * *} \\
(0.006)\end{array}$ & $\begin{array}{l}-0.330^{* * *} \\
(0.057)\end{array}$ & $\begin{array}{l}-0.094 \\
(0.060)\end{array}$ \\
\hline Constant & $\begin{array}{l}0.750^{* * *} \\
(0.011)\end{array}$ & $\begin{array}{l}0.341^{* * *} \\
(0.018)\end{array}$ & $\begin{array}{l}0.695^{\text {*** }} \\
(0.013)\end{array}$ & $\begin{array}{l}0.712^{* * *} \\
(0.049)\end{array}$ & $\begin{array}{l}0.822^{* * *} \\
(0.021)\end{array}$ & $\begin{array}{l}2.739^{* * *} \\
(0.387)\end{array}$ & $\begin{array}{l}1.906^{* * *} \\
(0.319)\end{array}$ \\
\hline Controls & Yes & Yes & Yes & Yes & Yes & Yes & Yes \\
\hline District FE & Yes & Yes & Yes & Yes & Yes & Yes & Yes \\
\hline Year FE & Yes & Yes & Yes & Yes & Yes & $\mathrm{n} / \mathrm{a}$ & $\mathrm{n} / \mathrm{a}$ \\
\hline$N$ & 13122 & 13122 & 13122 & 6508 & 13122 & 6624 & 6624 \\
\hline$R_{a d j}^{2}$ & 0.452 & 0.134 & 0.469 & 0.217 & 0.356 & 0.294 & 0.187 \\
\hline \multicolumn{8}{|c|}{ Panel B: Rural households } \\
\hline LSCM & $\begin{array}{l}0.005^{*} \\
(0.003)\end{array}$ & $\begin{array}{l}0.012^{* * *} \\
(0.004)\end{array}$ & $\begin{array}{l}0.011^{* * *} \\
(0.004)\end{array}$ & $\begin{array}{l}-0.025^{* *} \\
(0.012)\end{array}$ & $\begin{array}{l}0.004 \\
(0.006)\end{array}$ & $\begin{array}{l}-0.448^{* * *} \\
(0.065)\end{array}$ & $\begin{array}{l}-0.153^{* *} \\
(0.065)\end{array}$ \\
\hline$N L C M$ & $\begin{array}{l}0.017^{\text {*** }} \\
(0.003)\end{array}$ & $\begin{array}{l}0.046^{\text {*** }} \\
(0.004)\end{array}$ & $\begin{array}{l}0.043^{* * *} \\
(0.003)\end{array}$ & $\begin{array}{l}-0.023^{* *} \\
(0.011)\end{array}$ & $\begin{array}{l}-0.035^{* * *} \\
(0.006)\end{array}$ & $\begin{array}{l}-0.265^{* * *} \\
(0.057)\end{array}$ & $\begin{array}{l}-0.098 \\
(0.060)\end{array}$ \\
\hline$N L F M$ & $\begin{array}{l}0.012^{* * *} \\
(0.003)\end{array}$ & $\begin{array}{l}0.028^{* * *} \\
(0.004)\end{array}$ & $\begin{array}{l}0.040^{\text {**** }} \\
(0.004)\end{array}$ & $\begin{array}{l}-0.035^{* * *} \\
(0.011)\end{array}$ & $\begin{array}{l}-0.042^{* * *} \\
(0.006)\end{array}$ & $\begin{array}{l}-0.320^{* * *} \\
(0.059)\end{array}$ & $\begin{array}{l}-0.088 \\
(0.061)\end{array}$ \\
\hline Constant & $\begin{array}{l}0.725^{\text {**** }} \\
(0.017)\end{array}$ & $\begin{array}{l}0.401^{* * * *} \\
(0.024)\end{array}$ & $\begin{array}{l}0.669^{* * * *} \\
(0.019)\end{array}$ & $\begin{array}{l}0.633^{* * *} \\
(0.066)\end{array}$ & $\begin{array}{l}0.789^{* * * *} \\
(0.030)\end{array}$ & $\begin{array}{l}1.563^{* * *} \\
(0.492)\end{array}$ & $\begin{array}{l}1.169^{* * *} \\
(0.443)\end{array}$ \\
\hline Controls & Yes & Yes & Yes & Yes & Yes & Yes & Yes \\
\hline District FE & Yes & Yes & Yes & Yes & Yes & Yes & Yes \\
\hline Year FE & Yes & Yes & Yes & Yes & Yes & $\mathrm{n} / \mathrm{a}$ & $\mathrm{n} / \mathrm{a}$ \\
\hline$N$ & 7513 & 7513 & 7513 & 7513 & 7513 & 3337 & 3337 \\
\hline$R_{a d j}^{2}$ & 0.422 & 0.129 & 0.419 & 0.089 & 0.364 & 0.252 & 0.157 \\
\hline \multicolumn{8}{|c|}{ Panel C: Urban households } \\
\hline$L S C M$ & $\begin{array}{l}0.015^{* *} \\
(0.008)\end{array}$ & $\begin{array}{l}0.027^{*} \\
(0.016)\end{array}$ & $\begin{array}{l}0.034^{* * * *} \\
(0.009)\end{array}$ & $\begin{array}{l}0.056^{*} \\
(0.032)\end{array}$ & $\begin{array}{l}-0.027^{*} \\
(0.015)\end{array}$ & $\begin{array}{l}-0.134 \\
(0.242)\end{array}$ & $\begin{array}{l}-0.336 \\
(0.229)\end{array}$ \\
\hline$N L C M$ & $\begin{array}{l}0.022^{\text {**** }} \\
(0.008)\end{array}$ & $\begin{array}{l}0.026 \\
(0.016)\end{array}$ & $\begin{array}{l}0.041^{\text {**** }} \\
(0.009)\end{array}$ & $\begin{array}{l}0.022 \\
(0.032)\end{array}$ & $\begin{array}{l}-0.034^{* *} \\
(0.015)\end{array}$ & $\begin{array}{l}-0.056 \\
(0.242)\end{array}$ & $\begin{array}{l}-0.285 \\
(0.228)\end{array}$ \\
\hline$N L F M$ & $\begin{array}{l}0.004 \\
(0.009)\end{array}$ & $\begin{array}{l}0.014 \\
(0.018)\end{array}$ & $\begin{array}{l}0.029^{* * * *} \\
(0.010)\end{array}$ & $\begin{array}{l}0.026 \\
(0.037)\end{array}$ & $\begin{array}{l}-0.039^{* *} \\
(0.019)\end{array}$ & $\begin{array}{l}-0.320 \\
(0.309)\end{array}$ & $\begin{array}{l}-0.068 \\
(0.277)\end{array}$ \\
\hline Constant & $\begin{array}{l}0.784^{\text {**** }} \\
(0.016)\end{array}$ & $\begin{array}{l}0.368^{* * *} \\
(0.038)\end{array}$ & $\begin{array}{l}0.739^{* * *} \\
(0.017)\end{array}$ & $\begin{array}{l}0.830^{* * *} \\
(0.078)\end{array}$ & $\begin{array}{l}0.792^{* * *} \\
(0.033)\end{array}$ & $\begin{array}{l}4.331^{* * *} \\
(0.605)\end{array}$ & $\begin{array}{l}3.664^{* * *} \\
(0.462)\end{array}$ \\
\hline Controls & Yes & Yes & Yes & Yes & Yes & Yes & Yes \\
\hline District FE & Yes & Yes & Yes & Yes & Yes & Yes & Yes \\
\hline Year FE & Yes & Yes & Yes & Yes & Yes & $\mathrm{n} / \mathrm{a}$ & $\mathrm{n} / \mathrm{a}$ \\
\hline$N$ & 5609 & 5609 & 5609 & 5609 & 5609 & 3287 & 3287 \\
\hline$R_{a d j}^{2}$ & 0.404 & 0.150 & 0.435 & 0.176 & 0.278 & 0.241 & 0.188 \\
\hline
\end{tabular}

OLS estimation. See notes to Table 3. $L S C M$ equals 1 if lean season and close to food market and zero otherwise; $N L C M$ (NLFM) equals 1 if non-lean season and household is close to (far from) from the food market and zero otherwise. The reference category is lean season and far from the market $(L S F M)$. FE denotes fixed effects. The controls are listed in Table 1. Robust standard errors in parentheses

${ }^{*} p<0.10 ;{ }^{* *} p<0.05 ;{ }^{* * *} p<0.01$ 
Table 5 Interactive effects of road access and seasonality on household dietary diversity and food security

\begin{tabular}{|c|c|c|c|c|c|c|c|}
\hline & \multicolumn{2}{|c|}{ Dietary diversity } & \multicolumn{2}{|c|}{ Dietary diversity by source } & \multicolumn{3}{|c|}{ Food security } \\
\hline & (1) & $(2)$ & (3) & (4) & $(5)$ & $(6)$ & (7) \\
\hline & HDDI & NSTAPSH & Purchased HDDI & $\begin{array}{l}\text { Own food } \\
\text { HDDI }\end{array}$ & FDSH & CSI & HHS \\
\hline \multicolumn{8}{|c|}{ Panel A: National } \\
\hline$L S C R$ & $\begin{array}{l}0.009^{* * *} \\
(0.003)\end{array}$ & $\begin{array}{l}0.010^{* * * *} \\
(0.004)\end{array}$ & $\begin{array}{l}0.010^{* * *} \\
(0.004)\end{array}$ & $\begin{array}{l}-0.025^{* *} \\
(0.011)\end{array}$ & $\begin{array}{l}-0.010^{*} \\
(0.005)\end{array}$ & $\begin{array}{l}0.018 \\
(0.068)\end{array}$ & $\begin{array}{l}-0.081 \\
(0.064)\end{array}$ \\
\hline$N L C R$ & $\begin{array}{l}0.007^{* *} \\
(0.003)\end{array}$ & $\begin{array}{l}0.027^{* * * *} \\
(0.004)\end{array}$ & $\begin{array}{l}0.035^{* * *} \\
(0.004)\end{array}$ & $\begin{array}{l}-0.035^{\text {*** }} \\
(0.011)\end{array}$ & $\begin{array}{l}-0.040^{* * *} \\
(0.005)\end{array}$ & $\begin{array}{l}0.028 \\
(0.067)\end{array}$ & $\begin{array}{l}0.111^{*} \\
(0.062)\end{array}$ \\
\hline$N L F R$ & $\begin{array}{l}0.002 \\
(0.003)\end{array}$ & $\begin{array}{l}0.030^{* * *} \\
(0.004)\end{array}$ & $\begin{array}{l}0.037^{* * *} \\
(0.004)\end{array}$ & $\begin{array}{l}-0.037^{* * *} \\
(0.012)\end{array}$ & $\begin{array}{l}-0.044^{* * *} \\
(0.006)\end{array}$ & $\begin{array}{l}-0.069 \\
(0.073)\end{array}$ & $\begin{array}{l}-0.001 \\
(0.065)\end{array}$ \\
\hline Constant & $\begin{array}{l}0.757^{* * *} \\
(0.011)\end{array}$ & $\begin{array}{l}0.361^{\text {*** }} \\
(0.018)\end{array}$ & $\begin{array}{l}0.715^{* * *} \\
(0.012)\end{array}$ & $\begin{array}{l}0.706^{* * *} \\
(0.048)\end{array}$ & $\begin{array}{l}0.818^{* * *} \\
(0.021)\end{array}$ & $\begin{array}{l}2.424^{* * *} \\
(0.390)\end{array}$ & $\begin{array}{l}1.805^{* * *} \\
(0.316)\end{array}$ \\
\hline Controls & Yes & Yes & Yes & Yes & Yes & Yes & Yes \\
\hline District FE & Yes & Yes & Yes & Yes & Yes & Yes & Yes \\
\hline Year FE & Yes & Yes & Yes & Yes & Yes & $\mathrm{n} / \mathrm{a}$ & $\mathrm{n} / \mathrm{a}$ \\
\hline$N$ & 13187 & 13187 & 13187 & 13187 & 13187 & 6628 & 6628 \\
\hline $\begin{array}{l}R_{a d j}^{2} \\
\text { Panel B: Ru }\end{array}$ & 0.452 & 0.132 & 0.468 & 0.217 & 0.357 & 0.290 & 0.187 \\
\hline$L S C R$ & $\begin{array}{l}0.015^{\text {*** }} \\
(0.003)\end{array}$ & $\begin{array}{l}0.001 \\
(0.004)\end{array}$ & $\begin{array}{l}0.001 \\
(0.004)\end{array}$ & $\begin{array}{l}0.037^{* * *} \\
(0.012)\end{array}$ & $\begin{array}{l}0.001 \\
(0.006)\end{array}$ & $\begin{array}{l}-0.037 \\
(0.073)\end{array}$ & $\begin{array}{l}-0.124^{*} \\
(0.068)\end{array}$ \\
\hline$N L C R$ & $\begin{array}{l}0.004 \\
(0.003)\end{array}$ & $\begin{array}{l}0.030^{* * *} \\
(0.004)\end{array}$ & $\begin{array}{l}0.033^{* * *} \\
(0.004)\end{array}$ & $\begin{array}{l}-0.042^{* * *} \\
(0.012)\end{array}$ & $\begin{array}{l}-0.040^{* * *} \\
(0.006)\end{array}$ & $\begin{array}{l}0.019 \\
(0.072)\end{array}$ & $\begin{array}{l}0.115^{*} \\
(0.065)\end{array}$ \\
\hline$N L F R$ & $\begin{array}{l}0.000 \\
(0.003)\end{array}$ & $\begin{array}{l}0.031^{* * * *} \\
(0.005)\end{array}$ & $\begin{array}{l}0.035^{* * *} \\
(0.004)\end{array}$ & $\begin{array}{l}-0.036^{* * *} \\
(0.012)\end{array}$ & $\begin{array}{l}-0.041^{* * *} \\
(0.006)\end{array}$ & $\begin{array}{l}-0.000 \\
(0.077)\end{array}$ & $\begin{array}{l}0.028 \\
(0.066)\end{array}$ \\
\hline Constant & $\begin{array}{l}0.724^{* * * *} \\
(0.017)\end{array}$ & $\begin{array}{l}0.406^{* * *} \\
(0.024)\end{array}$ & $\begin{array}{l}0.675^{* * *} \\
(0.019)\end{array}$ & $\begin{array}{l}0.605^{* * * *} \\
(0.066)\end{array}$ & $\begin{array}{l}0.792^{* * *} \\
(0.030)\end{array}$ & $\begin{array}{l}1.365^{* * *} \\
(0.503)\end{array}$ & $\begin{array}{l}1.156^{\text {**** }} \\
(0.447)\end{array}$ \\
\hline Controls & Yes & Yes & Yes & Yes & Yes & Yes & Yes \\
\hline District FE & Yes & Yes & Yes & Yes & Yes & Yes & Yes \\
\hline Year FE & Yes & Yes & Yes & Yes & Yes & $\mathrm{n} / \mathrm{a}$ & $\mathrm{n} / \mathrm{a}$ \\
\hline$N$ & 7544 & 7544 & 7544 & 7544 & 7544 & 3337 & 3337 \\
\hline$R_{a d j}^{2}$ & 0.424 & 0.126 & 0.418 & 0.090 & 0.364 & 0.242 & 0.157 \\
\hline Panel C: Urb & & & & & & & \\
\hline$L S C R$ & $\begin{array}{l}0.019^{* *} \\
(0.007)\end{array}$ & $\begin{array}{l}-0.028^{*} \\
(0.017)\end{array}$ & $\begin{array}{l}0.007 \\
(0.009)\end{array}$ & $\begin{array}{l}0.096^{* *} \\
(0.049)\end{array}$ & $\begin{array}{l}-0.051^{* *} \\
(0.020)\end{array}$ & $\begin{array}{l}0.426^{*} \\
(0.248)\end{array}$ & $\begin{array}{l}0.119 \\
(0.257)\end{array}$ \\
\hline$N L C R$ & $\begin{array}{l}-0.012^{*} \\
(0.007)\end{array}$ & $\begin{array}{l}0.027 \\
(0.017)\end{array}$ & $\begin{array}{l}0.001 \\
(0.009)\end{array}$ & $\begin{array}{l}-0.126^{* * *} \\
(0.049)\end{array}$ & $\begin{array}{l}0.039^{*} \\
(0.020)\end{array}$ & $\begin{array}{l}-0.334 \\
(0.248)\end{array}$ & $\begin{array}{l}-0.065 \\
(0.256)\end{array}$ \\
\hline$N L F R$ & $\begin{array}{l}-0.016^{*} \\
(0.008)\end{array}$ & $\begin{array}{l}0.024 \\
(0.019)\end{array}$ & $\begin{array}{l}-0.003 \\
(0.010)\end{array}$ & $\begin{array}{l}-0.126^{* *} \\
(0.051)\end{array}$ & $\begin{array}{l}0.059^{* *} \\
(0.023)\end{array}$ & $\begin{array}{l}-0.701^{\text {** }} \\
(0.274)\end{array}$ & $\begin{array}{l}-0.058 \\
(0.283)\end{array}$ \\
\hline Constant & $\begin{array}{l}0.796^{* * *} \\
(0.013)\end{array}$ & $\begin{array}{l}0.394^{* * * *} \\
(0.034)\end{array}$ & $\begin{array}{l}0.769^{* * *} \\
(0.014)\end{array}$ & $\begin{array}{l}0.889^{* * *} \\
(0.071)\end{array}$ & $\begin{array}{l}0.780^{* * *} \\
(0.031)\end{array}$ & $\begin{array}{l}4.164^{* * *} \\
(0.550)\end{array}$ & $\begin{array}{l}3.358^{* * *} \\
(0.393)\end{array}$ \\
\hline Controls & Yes & Yes & Yes & Yes & Yes & Yes & Yes \\
\hline District FE & Yes & Yes & Yes & Yes & Yes & Yes & Yes \\
\hline Year FE & Yes & Yes & Yes & Yes & Yes & $\mathrm{n} / \mathrm{a}$ & $\mathrm{n} / \mathrm{a}$ \\
\hline$N$ & 5643 & 5643 & 5643 & 5643 & 5643 & 3291 & 3291 \\
\hline$R_{a d j}^{2}$ & 0.405 & 0.150 & 0.434 & 0.177 & 0.280 & 0.242 & 0.187 \\
\hline
\end{tabular}

OLS estimation. See notes to Table 3. LSCMR equals 1 if lean season and close to all-season road and zero otherwise; $N L C R$ (NLFR) equals 1 if non-lean season and household is close to (far from) from the road and zero otherwise. The reference category is lean season and far from the road $(L S F R)$. FE denotes fixed effects. The controls are listed in Table 1. Robust standard errors in parentheses

${ }^{*} p<0.10 ;{ }^{* *} p<0.05 ;{ }^{* * *} p<0.01$ 
Table 6 Potential pathways linking market access to improved food security

\begin{tabular}{|c|c|c|c|c|}
\hline & (1) & (2) & (3) & (4) \\
\hline & $\begin{array}{l}\text { Commercialization } \\
\text { index }\end{array}$ & $\begin{array}{l}\text { Sold produce } \\
\text { at } \\
\text { farmgate }\end{array}$ & $\begin{array}{l}\text { Operates a non- } \\
\text { farm enterprise }\end{array}$ & $\begin{array}{l}\text { Obtained credit } \\
\text { for consumer } \\
\text { goods }\end{array}$ \\
\hline \multicolumn{5}{|c|}{ Panel A: Market access } \\
\hline \multirow[t]{2}{*}{ Close to market } & $0.022^{* * *}$ & $-0.186^{*}$ & $0.364^{* * *}$ & $0.298^{* * *}$ \\
\hline & $(0.008)$ & $(0.098)$ & $(0.077)$ & $(0.094)$ \\
\hline \multirow[t]{2}{*}{ Constant } & $0.769^{* * *}$ & $-1.772^{*}$ & $-5.209^{* * *}$ & 0.278 \\
\hline & $(0.064)$ & $(0.926)$ & $(0.391)$ & $(0.633)$ \\
\hline Controls & Yes & Yes & Yes & Yes \\
\hline District FE & Yes & Yes & Yes & Yes \\
\hline Year FE & Yes & Yes & Yes & Yes \\
\hline$N$ & 4980 & 4016 & 13187 & 4418 \\
\hline \multicolumn{5}{|c|}{ Panel B: Interacting seasonality \& market access } \\
\hline \multirow[t]{2}{*}{$L S C M$} & 0.017 & $-0.156^{* *}$ & $0.316^{* * *}$ & $0.267^{* * *}$ \\
\hline & $(0.012)$ & $(0.077)$ & $(0.061)$ & $(0.078)$ \\
\hline \multirow[t]{2}{*}{$N L C M$} & $0.019^{*}$ & 0.101 & $0.187^{* * *}$ & $0.155^{* *}$ \\
\hline & $(0.010)$ & $(0.072)$ & $(0.063)$ & $(0.078)$ \\
\hline \multirow[t]{2}{*}{$N L F M$} & $0.046^{* * *}$ & 0.037 & $0.319^{* * * *}$ & $0.282^{* * * *}$ \\
\hline & $(0.011)$ & $(0.077)$ & $(0.060)$ & $(0.076)$ \\
\hline \multirow[t]{2}{*}{ Constant } & $0.754^{* * *}$ & $-1.110^{* * *}$ & $-3.109^{* * *}$ & -0.003 \\
\hline & $(0.065)$ & $(0.520)$ & $(0.228)$ & $(0.383)$ \\
\hline Controls & Yes & Yes & Yes & Yes \\
\hline District FE & Yes & Yes & Yes & Yes \\
\hline Year FE & Yes & Yes & Yes & Yes \\
\hline$N$ & 4980 & 4016 & 13187 & 4418 \\
\hline
\end{tabular}

A household is considered to be close to the market if the time to the nearest market is 60 min or less. Results in column 1 are based on OLS estimation, and those in columns in 2-4 are probit estimations. See Table 1 for a list of control variables. Robust standard errors in parentheses

${ }^{*} p<0.10 ;{ }^{* *} p<0.05 ;{ }^{* * *} p<0.01$ of October and November on household dietary diversity become smaller and weaker as diverse foods become more available and accessible during the harvest season.

Turning to household food security, the results in model 3 show that the months of January and February are associated with significantly lower food share of total consumption expenditure (a proxy of income): -0.064 and -0.032 respectively. This signifies that the households spent significantly less on food as they become richer and more food secure, potentially from lower food prices and increased food availability as well as cash incomes during these harvest months. However, the effect of seasonality on the food share of household consumption expenditure tends to be positive as households approach the lean months. The positive and statistically significant effects of the seasonal dummies for June through October on the food share of total household expenditure suggests heightened food insecurity over this period, during which food supply becomes limited, food prices hit the roof, and effective purchasing power and other means of accessing food diminish considerably. The resultant negative dietary changes are previously seen in significantly lower dietary diversity and share of food expenditure on non-staple foods (models 1-2).

Although they remain significantly higher compared to December, the models 4 and 5 show a general decline in the effects of seasonal variables on CSI and HHS throughout the year. In particular, the effect size of seasonality on both food insecurity indicators declined consistently from January to May, fluctuated from June to October, before resuming the downward trend as the lean (food-deficit) season gives way to the harvest (food sufficient) period. Out of eleven, the coefficients of eight monthly dummies are positive and statistically significant in models 4 and 5, demonstrating that Sierra Leonean households remain vulnerable to food insecurity throughout the year, even in the harvest months. This may compel households to adopt severe coping strategies - including limiting dietary frequency frequently, quality and quantity - to deal with short-term food inadequacy.

These results are generally consistent with those reported in Table 3, with seasonality captured by agricultural season dummies. At the national level, we find that both dietary 
diversity and food security deteriorate during the postharvest and growing (lean) seasons, relative to the harvest season. The negative effects of post-harvest and lean seasons on household diets and food security are jointly significant in all models of panel $A$. This is shown by the $F$ statistics and its $p$-values, which suggest a rejection of the null hypothesis that both seasons jointly have no significant effect on food consumption in Sierra Leone.

As evidenced by the magnitude of the coefficients in panel $A$ of Table 3 , the largest decline in dietary quality (models 1-2) occurs during the lean season, the period of most acute food shortage. In particular, the lean season is associated with 0.012 units (model 1) decline in dietary diversity and 0.026 units (model 2) reduction in non-staple share of the food budget, compared to the harvest season. Dietary quality also declines during the post-harvest season, but by smaller margins compared to the hunger season. While the growing/lean season is also significantly associated with higher shares of food expenditure (model 3), we do not find its effects on other food insecurity indicators statistically to be significant (models 4-5). Nonetheless, as shown by the Wald test results, both seasonal dummies are jointly significant in explaining the variations in the food security variables over the year.

In terms of locality, the results in panels $B$ and $C$ (Table 3) generally reveal that seasonality is more pronounced among rural households than urban residents. The coefficients of the seasonal variables are (absolutely) larger and more statistically significant for rural households than urban households. This portrays that agricultural seasonality may induce considerable fluctuations in the dietary diversity and food security of rural households than urban households. This is not surprising because rural livelihoods are largely agriculturalbased and strongly intertwined with the seasonal dynamics of agricultural production. Compared to the harvest season (base category), the results in panel $B$ suggest that rural households surveyed during the lean season experienced significant reductions in dietary diversity, and the share of non-staple foods (models 1-2), as well as significant increments in food insecurity (models 3-4). The estimated coefficients are statistically significant, indicating that the hunger season is an important contributor to low dietary diversity and high food insecurity in rural areas. This finding is consistent with Sibhatu and Qaim (2017) who reported that the dietary diversity of rural households in Ethiopia decreases significantly during the growing season, mainly due to lower availability from subsistence production.

With respect to urban areas, the results in panel $C$ provide mixed and non-robust evidence of the effects of farming seasons on dietary diversity and food security. What is worth noting, however, is the general lack of statistical significance of the effects of the lean (growing) season on these welfare outcomes. This indicates that increased food insecurity in
Sierra Leone during this time of the year may be more of a rural occurrence than an urban one. A possible reason is that urban households, which are less dependent on subsistence farming for foods, may have stable access to food from local and international markets because of their better connectivity.

These results highlight the importance of seasonality in shaping the dietary quality and food security, particularly in agrarian settings. The results reveal that household dietary diversity and food security in Sierra Leone primarily follow the regular patterns of agricultural production - deteriorating significantly during the preharvest months and improving markedly during harvest and immediate postharvest months. This finding is consistent with fluctuations in food consumption patterns over the agricultural cycle in Mozambique (Handa \& Mlay, 2006). In a related study, Chirwa et al. (2012) examined household consumption expenditure in Malawi. They showed that the incidence of poverty in Malawi is significantly affected by seasonality, with estimated poverty rates likely to be higher during the hunger season than in the post-harvest season.

\subsection{The role of market access in mitigating seasonal food insecurity}

The results presented in the previous section demonstrate that household diets and food security are subject to significant seasonality - with no consideration for market access. The extent to which households have access to or are engaged in markets is vital for food security in all of its dimensions - availability, accessibility, utilization, and stability. In this section, we analyse the interaction effects of market access and seasonality on household dietary diversity and food security. Given that insufficient food access constitutes one of the most important underlying causes of malnutrition, this analysis is pertinent for policies aimed at smoothing food consumption within the year and reducing vulnerability to seasonal food insecurity.

Table 4 reports the results based on Eq. (3), which relates several indicators of household dietary diversity and food security to seasonally-defined market access variables and all the controls included in previous models. Panel A reports the results at the country level, whereas Panels $\mathrm{B}$ and $\mathrm{C}$ present sub-sample results by area of residence. The reference group consists of households surveyed in the lean season and located far from the food market ( $L S F M)$. The magnitude of seasonal changes in dietary diversity and food security with respect to the degree of market access are captured by the coefficients of $L S C M, N L C M$, and NLFM. Similar results are reported in Table 5 using proximity to an all-season road as an alternative indicator of market access. The results are generally consistent with findings in Table 4. However, the discussion in the remainder of this section is focused on our preferred results in Table 4. 
Unsurprisingly, compared to the base category, the non-lean season indicators are associated with significantly higher dietary diversity (models $1-2$ ), irrespective of proximity to markets. This result may be explained by the increased availability of diverse nutrient-dense foods (at affordable prices) during the non-lean season. However, it is interesting to note that, the effect sizes of $N L C M$ are generally larger than those of $N L F M$ across the different specifications. This suggests that even in the non-lean season households that have better access to markets enjoy more diverse diets than those with poorer access. These results highlight the importance of better market access in preventing drastic reductions in dietary quality at certain times of the year, resulting particularly from the seasonal dynamics of agricultural production.

Models 3-4 in Tables 4 and 5 demonstrate that marketpurchased foods contribute significantly to higher dietary diversity than from own-produced food in both lean and non-lean seasons. For instance, the results from models 3 in Table 4 show that during the lean season, the HDDI of purchased foods is 0.022 units (model 3, panel A) higher for households ( 0.011 for rural and 0.034 for urban households) near food markets than households isolated from markets. This result also holds in the non-lean season, considering the positive difference between the coefficients of $N L C M$ and $N L F M$ in models 3: nearness to food markets increases the diversity of purchased foods. On the other hand, the interaction effects of seasonality and market access on dietary diversity from subsistence production (models 4) are negative, indicating that market access has a limited impact on household dietary diversity and food security through the subsistence pathway. This may be due to limited productivity and availability of diverse foods from own production. Because of this, subsistence production alone cannot make available the needed diverse foods in sufficient quantities for improved food and nutrition security throughout the year.

With respect to food security, $L S C M$ is associated with reduction in the FDSH, CSI and HHS (models 5-7 in Table 4). At the country level (panel A), the coefficients are rightly and signed strongly significant (except for model 5), indicating the being closer to markets is associated with better food security outcomes during the lean season than being farther away (in same season). Models 6-7 of panels B and $\mathrm{C}$ show that food security enhancing effects of better market access during the lean season statistically stronger for rural households than urban households. These results demonstrate that, during the lean season, households that have better access to markets experience significantly less (severe) hunger and adopt less harmful coping strategies in the face of short-term food deprivation. As one would expect, dietary diversity food security also improves during the non-lean season with proximity to food markets. This is evidenced by mostly positive effects of $N L C M$ and $N L F M$ on the dietary diversity measures (models 1-3) and negative effects on the food insecurity measures (models 5-7). For rural households in particular, the results are largely significant, indicating that improved access to food markets can be instrumental in preventing seasonality-induced reductions in dietary quality as well as shortfalls in food access and its attendant use of severe coping strategies in rural areas, where the burdens of food insecurity and malnutrition are heaviest. With most households sourcing majority of their foods from markets, the results suggest that, by increasing availability and access to a variety of foods throughout the year, improved market access has the potential of mitigating seasonal fluctuations in household diets and food security. These findings are also consistent with recent studies that underlined the important role of markets for smallholder diets and nutrition (Muthini et al., 2020; Sibhatu \& Qaim, 2018; Usman \& Callo-Concha, 2021).

\subsection{Exploring potential pathways}

The results presented in the previous section suggest that closeness to markets holds significant potential to mitigate seasonal fluctuations in dietary diversity and food security. The results in Table 6 explore the potential pathways that could underlie this finding. Market participation is measured by the crops commercialization index and an indicator of whether or not the household sold at the farmgate (models 1-2). Access to off-farm incomes is captured by whether or not any household member operates a non-farm business enterprise (model 3). Lastly, the access to credit pathway is examined in model 4.

The results show that rural households with better market access are associated with a significantly higher level of commercialization and lower propensity to sell at the farmgate. As discussed above, the literature has shown that transaction costs decline, and relative market prices improve, with reductions in travel time or distance between production and exchange locations (Fafchamps \& Hill, 2005; Renkow et al., 2004). This improves the profitability of transporting and selling their output at the nearest market, instead of selling them at lower prices at the farmgate (Fafchamps \& Hill, 2005). The results in Panel B reveal that the effect of proximity to markets on commercialization is strongest in the non-lean seasons when rural farm households greatly need to reach markets to sell their produce.

The results also disclose that households located in areas with better market access also have a higher propensity of engaging in off-farm economic ventures than isolated households (model 3). This may be because households in remote areas have limited access to thicker markets - with many buyers and sellers - which render the operation of non-farm enterprises less economically viable. From a food security 
perspective, operating off-farm enterprises provides households with an alternative source of income, with which they can bridge deficits in household food supplies, especially in the lean season. The presence of an off-farm source of income in the household is associated with more diverse diets and less seasonal variation in consumption over the year in Mozambique (Handa \& Mlay, 2006).

Lastly, closeness to markets is found to be strongly associated with the likelihood of getting credit for consumption purposes. Most Sierra Leonean households obtain credit from families, friends, and neighbours. However, market traders, being the second most important source of credit (Statistics Sierra Leone, 2019a), are also instrumental in easing financing constraints on households and improving food security. In the face of limited or non-existent credit from formal financial institutions, access to (output) markets can contribute to improved food security by connecting financially-constrained households to market traders, who offer credits in the form of cash, foods, or inputs. As shown by the results in model 4 , this can enable households to bridge short term or seasonal food shortages. These results are also consistent with findings in other studies. For instance, Schrieder and Heidhues (1995) have shown that access to production and consumption credits has a positive and significant impact on rural households' food security in Cameroon. Annim and Frempong (2018) have also shown that access to credit contributes to the consumption of diversified diets in Ghana.

\section{Conclusions}

This study examines the role of seasonality in shaping household dietary diversity and food security over the agricultural production cycle in Sierra Leone. The analyses of household consumption patterns over the year and agricultural seasons, using the 2011 and 2018 SLIHS datasets, reveal that seasonality exerts considerable fluctuations in the dietary diversity and food security of Sierra Leonean households. We find that household diets and food security primarily follow the regular patterns of agricultural production: improving during the harvesting season and worsening in the post-harvest period. We find that rural households are most vulnerable to food insecurity during the lean season, when nutritionallydamaging coping strategies are usually deployed. From a public policy standpoint, the study demonstrates that proximity to food markets holds beneficial effects of mitigating the seasonality in household dietary quality and food security. In particular, we find that households with better market access consume more diverse diets and are more food secure throughout the year than remoter households. The results also show that nearness to food markets facilitates all-year-round access to and intake of nutritious non-staple food groups (including meats, fish and seafood, dairy, legumes, and vegetables). Lastly, the results reveal that closeness to markets can smoothen seasonal fluctuations in household dietary diversity and food security by enhancing commercialization, access to off-farm income-generating opportunities, and access to credit - all of which are important in bridging short-term household food deficits.

A key policy implication of these findings is that fostering access to markets and integration for remoter households can significantly reduce vulnerability to seasonal food insecurity and avert the use of deleterious coping strategies. The reason is that, in a country where households predominantly source their foods from markets, poor market access significantly reduces food access and availability by impeding the cost-effective movement of foodstuffs from surplus areas to deficit areas. More distant markets are associated with higher production costs and lower profitability (and income) for sellers and higher transportation costs and food prices (lower effective purchasing power) for buyers, all of which exacerbate seasonal fluctuations in food availability and access at both local and national levels. In Sierra Leone, markets are not well-integrated, as majority of households live in communities with no functional market, and have to travel over an hour to reach the nearest market. Poor road conditions severely inhibit physical access to markets. Most Sierra Leonean communities are served by dirt or feeder roads, which become impassable during the rainy (and lean) season, when food shortage is rife, and households gravely need to reach markets to purchase and sell food items. Lengthy distances to roads and markets do worsen not only the energy and time burden on households but also their already precarious food and nutrition security situation. Hence based on the results, we conclude that development strategies aimed at strengthening market access through improved market infrastructure and roads can significantly contribute to year-long food consumption smoothing, improved dietary diversity, and overall food and nutrition security in Sierra Leone and Africa at large. 


\section{Appendix}

Table 7 Description of variables

\begin{tabular}{|c|c|}
\hline Variables & Measurement description \\
\hline \multicolumn{2}{|l|}{ Dietary diversity \& food security indicators } \\
\hline HH dietary diversity index, HDDI (0-1) & $\begin{array}{l}\text { Berry index of dietary diversity based on the shares of food groups in total food } \\
\text { expenditure }\end{array}$ \\
\hline Purchased HDDI & $\begin{array}{l}\text { Simpson diversity index or Berry index to measure dietary diversity based on the } \\
\text { shares of food groups in purchased food expenditure }\end{array}$ \\
\hline Own food HDDI & $\begin{array}{l}\text { Berry index of dietary diversity based on the shares of food groups in own produced } \\
\text { food expenditure }\end{array}$ \\
\hline Share of food in HH consumption exp & Total food expenditure divided by total consumption expenditure \\
\hline Share of staple foods exp. in the food budget & $\begin{array}{l}\text { Total food expenditure on cereals, and roots and tubers divided by total food expendi- } \\
\text { ture }\end{array}$ \\
\hline Share of non-staple foods exp. in food budget & $\begin{array}{l}\text { Total expenditure on non-staple foods (meat, fish, fruits, vegetables, dairy, legumes, } \\
\text { and oils) divided by total food expenditure }\end{array}$ \\
\hline Coping strategy index & $\begin{array}{l}\text { Weighted sum of the frequency (days) of a household adopting five pre-determined } \\
\text { coping strategies (when faced with having not enough food or money to buy food) } \\
\text { during the seven days preceding the survey, with their respective severity values as } \\
\text { weights. Based Maxwell and Caldwell (2008) the coping strategies (and their severity } \\
\text { weights) are (i) rely on less preferred or less expensive foods (1); (ii) borrow food or } \\
\text { rely on help from friends or relatives (2); (iii) limit portion size at mealtimes (1); (iv) } \\
\text { restrict consumption by adults in order for small children to eat (3); and (v) reduce the } \\
\text { number of meals eaten in a day (1) }\end{array}$ \\
\hline
\end{tabular}

Household hunger scale (0-6)

An experienced-based household food deprivation scale. It is based on the frequencies of a household experiencing the following related conditions during the 4 weeks / 30 days preceding the survey: (i) there was ever no food to eat of any kind in the household because of lack resources to get food; (ii) respondent or any household member going to sleep at night hungry because there was not enough food; (iii) respondent or any household member going a whole day and night without eating anything at all because there was not enough food (Ballard et al., 2011)

\section{Seasonality \& market access}

Post-harvest season (February-May) (1/0)

Lean \& growing season (June-September) (1/0)

Harvest season (October-January) (1/0)

Equals 1 if the household was interviewed during February to May, and 0 otherwise

Equals 1 if the household was interviewed during June to September, and 0 otherwise

Equals 1 if the household was interviewed during October to January, and 0 otherwise

Close to food market (or road) ( $=1$ if time is $\leq 60 \mathrm{~min}$ )

Equals 1 if it takes the household $60 \mathrm{~min}$ or less to reach the nearest food market (or all-season road) using the most frequent means, and 0 otherwise

Lean \& close to food market (or road) (1/0)

Equals 1 if the household was interviewed during lean season and dwells close to food market (or road), and 0 otherwise

Lean season \& far from food market (or road) (1/0)

Equals 1 if the household was interviewed during lean season (June-September) and lives far from food market (or road), and 0 otherwise Non-lean season \& close to food market (or road) (1/0) Equals 1 if the household was interviewed during non-lean season (February-May and
October-January), and dwells to food market (or road), and 0 otherwise

Non-lean season \& far from food market (or road) (1/0) Equals 1 if the household was interviewed during non-lean season (February-May and October-January) and dwells far from food market (or road), and 0 otherwise

\section{Control variables}

HHD is male (1/0)

Age of HHD (years)

HHD in monogamous marriage (1/0)

HHD in polygamous marriage (1/0)

HHD is divorced, separated or widowed (1/0)

HHD is never married (1/0)

No. of HHM aged 0-14 years

No. of HHM aged 15-64 years

No. of HHM aged over 64 years

Equals 1 if the household head is a male, 0 otherwise

Age of household head in years

Equals 1 if the household head is in a monogamously marriage, 0 otherwise

Equals 1 if the household head is in a polygamous marriage, 0 otherwise

Equals 1 if the household head is divorced, separated or widowed, 0 otherwise

Equals 1 if the household head has never married, 0 otherwise

Number of household members aged $0-14$ years

Number of household members aged 15-64 years

Number of household members above 64 years 
Table 7 (continued)

\begin{tabular}{|c|c|}
\hline Variables & Measurement description \\
\hline HHD is waged/salaried employee (1/0) & Equals 1 if the household head is a waged/salaried employee, 0 otherwise \\
\hline HHD is employed in agriculture $(1 / 0)$ & Equals 1 if the household head is employed in the agriculture sector, 0 otherwise \\
\hline HHD is employed in non-agriculture $(1 / 0)$ & Equals 1 if the household head is employed in the non-agriculture, 0 otherwise \\
\hline HH owns any livestock (1/0) & Equals 1 if the household owns any livestock, 0 otherwise \\
\hline HH owns any agricultural land (1/0) & Equals 1 if the household is owns any agricultural land, 0 otherwise \\
\hline HH wealth index $(0-100)$ & Asset-based wealth index from principal component analysis \\
\hline HHD is Christian (1/0) & Equals 1 if the household is a Christian, 0 otherwise \\
\hline HHD is Muslim (1/0) & Equals 1 if the household is a Muslim, 0 otherwise \\
\hline HHD has other or no religion $(1 / 0)$ & Equals 1 if the household is has other or no religion, 0 otherwise \\
\hline HHD has no education $(1 / 0)$ & Equals 1 if the household has no formal education, 0 otherwise \\
\hline HHD has primary education $(1 / 0)$ & Equals 1 if the household obtained only primary education, 0 otherwise \\
\hline HHD has secondary education $(1 / 0)$ & Equals 1 if the household obtained only secondary, 0 otherwise \\
\hline HHD has post-secondary education (1/0) & Equals 1 if the household obtained post-secondary education, 0 otherwise \\
\hline HHD has college degree $(1 / 0)$ & Equals 1 if the household obtained a university degree, 0 otherwise \\
\hline Time to drinking water source $\leq 30 \min (1 / 0)$ & Equals 1 if time to drinking water source is $30 \mathrm{~min}$ or less, 0 otherwise \\
\hline Time to drinking water source $31-60 \min (1 / 0)$ & Equals 1 if time to drinking water source is between 31 and $60 \mathrm{~min}, 0$ otherwise \\
\hline Time to drinking water source $>60 \min (1 / 0)$ & Equals 1 if time to drinking water source is more than $60 \mathrm{~min}, 0$ otherwise \\
\hline Time to health clinic $\leq 30 \min (1 / 0)$ & Equals 1 if time to health clinic is 30 min or less, 0 otherwise \\
\hline Time to health clinic $31-60 \min (1 / 0)$ & Equals 1 if time to health clinic is between 31 and $60 \mathrm{~min}, 0$ otherwise \\
\hline Time to health clinic $>60 \min (1 / 0)$ & Equals 1 if time to health clinic is more than $60 \mathrm{~min}, 0$ otherwise \\
\hline \multicolumn{2}{|l|}{ Pathway variables } \\
\hline Share of gross value of farm output sold $(0-1)$ & $\begin{array}{l}\text { Value of food and cash crops sold divided by the total value of food and cash crops } \\
\text { produced during the } 12 \text { months prior to the survey }\end{array}$ \\
\hline Sold crops to farm gate buyer $(1 / 0)$ & $\begin{array}{l}\text { Equals } 1 \text { if any household member sold any crops/farm produce at the farm gate during } \\
\text { the previous agricultural season, } 0 \text { otherwise }\end{array}$ \\
\hline HH operates a non-farm enterprise $(1 / 0)$ & $\begin{array}{l}\text { Equals } 1 \text { if any household member operates and/or earns income from non-farm busi- } \\
\text { ness venture in the past } 12 \text { months, } 0 \text { otherwise }\end{array}$ \\
\hline $\mathrm{HH}$ accessed credit for consumer goods $(1 / 0)$ & $\begin{array}{l}\text { Equals } 1 \text { if any household member obtained credit (cash or in-kind) for consumption } \\
\text { purposes, } 0 \text { otherwise }\end{array}$ \\
\hline
\end{tabular}


Table 8 Summary statistics of dietary diversity, food security and market access indicators by season

\begin{tabular}{|c|c|c|c|c|c|}
\hline Panel A: SLIHS 2011 & Total & $\begin{array}{l}\text { Post-harvest } \\
\text { Feb-May }\end{array}$ & $\begin{array}{l}\text { Growing/lean } \\
\text { Jun-Sept }\end{array}$ & $\begin{array}{l}\text { Harvest } \\
\text { Oct-Jan }\end{array}$ & F-test \\
\hline HDDI & $\begin{array}{l}0.750 \\
(0.099)\end{array}$ & $\begin{array}{l}0.751 \\
(0.096)\end{array}$ & $\begin{array}{l}0.739 \\
(0.104)\end{array}$ & $\begin{array}{l}0.762 \\
(0.095)\end{array}$ & $28.52^{* * *}$ \\
\hline NSTAPSH & $\begin{array}{l}0.478 \\
(0.143)\end{array}$ & $\begin{array}{l}0.479 \\
(0.142)\end{array}$ & $\begin{array}{l}0.454 \\
(0.136)\end{array}$ & $\begin{array}{l}0.505 \\
(0.146)\end{array}$ & $71.16^{* * *}$ \\
\hline Purchased HDDI & $\begin{array}{l}0.732 \\
(0.112)\end{array}$ & $\begin{array}{l}0.737 \\
(0.108)\end{array}$ & $\begin{array}{l}0.711 \\
(0.120)\end{array}$ & $\begin{array}{l}0.749 \\
(0.103)\end{array}$ & $64.85^{* * *}$ \\
\hline Own food HDDI & $\begin{array}{l}0.724 \\
(0.335)\end{array}$ & $\begin{array}{l}0.739 \\
(0.329)\end{array}$ & $\begin{array}{l}0.704 \\
(0.338)\end{array}$ & $\begin{array}{l}0.731 \\
(0.337)\end{array}$ & $7.08^{* * *}$ \\
\hline FDSH & $\begin{array}{l}0.627 \\
(0.175)\end{array}$ & $\begin{array}{l}0.627 \\
(0.173)\end{array}$ & $\begin{array}{l}0.645 \\
(0.174)\end{array}$ & $\begin{array}{l}0.604 \\
(0.176)\end{array}$ & $30.40^{* * * *}$ \\
\hline Close to market & $\begin{array}{l}0.675 \\
(0.468)\end{array}$ & $\begin{array}{l}0.612 \\
(0.487)\end{array}$ & $\begin{array}{l}0.668 \\
(0.471)\end{array}$ & $\begin{array}{l}0.760 \\
(0.427)\end{array}$ & $54.79^{* * * *}$ \\
\hline Close to road & $\begin{array}{l}0.754 \\
(0.431)\end{array}$ & $\begin{array}{l}0.723 \\
(0.448)\end{array}$ & $\begin{array}{l}0.755 \\
(0.430)\end{array}$ & $\begin{array}{l}0.792 \\
(0.406)\end{array}$ & $13.62^{* * * *}$ \\
\hline $\begin{array}{l}N \\
\text { Panel B: SLIHS } 2018\end{array}$ & 6628 & 2349 & 2322 & 1957 & \\
\hline HDDI & $\begin{array}{l}0.861 \\
(0.057)\end{array}$ & $\begin{array}{l}0.864 \\
(0.056)\end{array}$ & $\begin{array}{l}0.858 \\
(0.058)\end{array}$ & $\begin{array}{l}0.861 \\
(0.056)\end{array}$ & $5.58^{* * *}$ \\
\hline NSTAPSH & $\begin{array}{l}0.450 \\
(0.123)\end{array}$ & $\begin{array}{l}0.451 \\
(0.117)\end{array}$ & $\begin{array}{l}0.449 \\
(0.129)\end{array}$ & $\begin{array}{l}0.451 \\
(0.122)\end{array}$ & 0.27 \\
\hline Purchased HDDI & $\begin{array}{l}0.854 \\
(0.066)\end{array}$ & $\begin{array}{l}0.856 \\
(0.076)\end{array}$ & $\begin{array}{l}0.846 \\
(0.062)\end{array}$ & $\begin{array}{l}0.861 \\
(0.059)\end{array}$ & $28.62^{* * * *}$ \\
\hline Own food HDDI & $\begin{array}{l}0.755 \\
(0.305)\end{array}$ & $\begin{array}{l}0.719 \\
(0.322)\end{array}$ & $\begin{array}{l}0.801 \\
(0.290)\end{array}$ & $\begin{array}{l}0.746 \\
(0.296)\end{array}$ & $41.60^{* * * *}$ \\
\hline FDSH & $\begin{array}{l}0.456 \\
(0.161)\end{array}$ & $\begin{array}{l}0.433 \\
(0.150)\end{array}$ & $\begin{array}{l}0.485 \\
(0.158)\end{array}$ & $\begin{array}{l}0.451 \\
(0.170)\end{array}$ & $61.56^{* * *}$ \\
\hline CSI & $\begin{array}{l}7.979 \\
(8.329)\end{array}$ & $\begin{array}{l}8.522 \\
(8.739)\end{array}$ & $\begin{array}{l}7.623 \\
7.904)\end{array}$ & $\begin{array}{l}7.794 \\
(8.301)\end{array}$ & $7.26^{* * *}$ \\
\hline HHS & $\begin{array}{l}1.172 \\
(1.134)\end{array}$ & $\begin{array}{l}1.220 \\
(1.180)\end{array}$ & $\begin{array}{l}1.147 \\
(1.100)\end{array}$ & $\begin{array}{l}1.149 \\
(1.119)\end{array}$ & $3.02^{* *}$ \\
\hline Close to market & $\begin{array}{l}0.790 \\
(0.408)\end{array}$ & $\begin{array}{l}0.768 \\
(0.422)\end{array}$ & $\begin{array}{l}0.824 \\
(0.381)\end{array}$ & $\begin{array}{l}0.777 \\
(0.416)\end{array}$ & $11.83^{\text {**** }}$ \\
\hline Close to road & $\begin{array}{l}0.820 \\
(0.384)\end{array}$ & $\begin{array}{l}0.794 \\
(0.405)\end{array}$ & $\begin{array}{l}0.859 \\
(0.348)\end{array}$ & $\begin{array}{l}0.807 \\
(0.395)\end{array}$ & $17.67^{* * * *}$ \\
\hline$N$ & 6628 & 2203 & 2210 & 2215 & \\
\hline
\end{tabular}

The figures are mean values. Standard deviations are in parenthesis Source: Own calculations based on SLIHS $2011 \& 2018$

**, *** indicate statistical significance at $1 \%$ and $5 \%$ respectively based ANOVA test for difference in means across seasons 
Funding Open Access funding enabled and organized by Projekt DEAL. This work was financially supported by the Welthungerhilfe (WHH) under the SLE-1047 project, and the German Federal Ministry for Economic Cooperation and Development (BMZ) under Grant Number: 2014-06891. The first author also acknowledges funding from BMZ through the German Academic Exchange Service (DAAD) scholarship programme.

\section{Declarations}

Conflicts of interest The authors declared that they have no conflict of interest.

Open Access This article is licensed under a Creative Commons Attribution 4.0 International License, which permits use, sharing, adaptation, distribution and reproduction in any medium or format, as long as you give appropriate credit to the original author(s) and the source, provide a link to the Creative Commons licence, and indicate if changes were made. The images or other third party material in this article are included in the article's Creative Commons licence, unless indicated otherwise in a credit line to the material. If material is not included in the article's Creative Commons licence and your intended use is not permitted by statutory regulation or exceeds the permitted use, you will need to obtain permission directly from the copyright holder. To view a copy of this licence, visit http://creativecommons.org/licenses/by/4.0/.

\section{References}

Abay, K., \& Hirvonen, K. (2017). Does Market Access Mitigate the Impact of Seasonality on Child Growth? Panel Data Evidence from Northern Ethiopia. Journal of Development Studies, 53(9), 1414-1429. https://doi.org/10.1080/00220388.2016.1251586

Abdulai, A. (2000). Spatial price transmission and asymmetry in the Ghanaian maize market. Journal of Development Economics, 63, 327-349.

Alderman, H., Hoddinott, J., \& Kinsey, B. (2006). Long term consequences of early childhood malnutrition. Oxford Economic Papers, 58(3), 450-474. https://doi.org/10.1093/oep/gpl008

Alderman, H., \& Paxson, C. H. (1994). Do the Poor Insure? A Synthesis of the Literature on Risk and Consumption in Developing Countries. In E. L. Bacha (Ed.), Economics in a Changing World: Volume 4: Development, Trade and the Environment (pp. 48-78). Palgrave Macmillan UK. https://doi.org/10.1007/ 978-1-349-23458-5_3

Amadu, F. O., Silvert, C., Eisenmann, C., Mosiman, K., \& Liang, R. (2017). Sierra Leone Landscape Analysis. https://www.g-fras.org/en/ component/phocadownload/category/93-reviews-and-assessments. html?download=821: sierra-leone-landscape-analysis

Anderson, C. L., Reynolds, T., Merfeld, J. D., \& Biscaye, P. (2018). Relating Seasonal Hunger and Prevention and Coping Strategies: A Panel Analysis of Malawian Farm Households. Journal of Development Studies, 54(10), 1737-1755. https://doi.org/10. 1080/00220388.2017.1371296

Annim, S. K., \& Frempong, R. B. (2018). Effects of access to credit and income on dietary diversity in Ghana. Food Security, 10(6), 1649-1663. https://doi.org/10.1007/s12571-018-0862-8

Arimond, M., Wiesmann, D., Becquey, E., Daniels, M., Deitchler, M., Fanou, N., Kennedy, G., Martin-Prevel, Y., Torheim, L. E., Ferguson, E., Joseph, M., \& Carriquiry, A. (2011). Dietary diversity as a measure of the micronutrient adequacy of women's diets in resource-poor areas: Summary of results from five sites. Washington, DC: FANTA-2 Bridge, FHI 360. https://www.fantaproject.org/sites/default/files/ resources/WDDP_Summary_Report_Jul2011.pdf
Ballard, T., Swindale, A., \& Deitchler, M. (2011). Household Hunger Scale : Indicator Definition and Measurement Guide. Washington, DC: Food and Nutrition Technical Assistance II Project, FHI 360. https://www.fsnnetwork.org/sites/default/files/hhs_ indicator_guide_03212012.pdf

Bhutta, Z. A., Das, J. K., Rizvi, A., Gaffey, M. F., Walker, N., Horton, S., Webb, P., Lartey, A., \& Black, R. E. (2013). Evidence-based interventions for improvement of maternal and child nutrition: What can be done and at what cost? The Lancet, 382(9890), 452 477. https://doi.org/10.1016/S0140-6736(13)60996-4

Binns, T., \& Bateman, J. (2017). Rural livelihoods and food security: longterm insights from Sierra Leone's Eastern Province. Geographical Research, 55, 156- 165. https://doi.org/10.1111/1745-5871.12204

Bonuedi, I. (2021). The roles of nutrition-sensitive interventions and market access in enhancing household food security and resilience in Sierra Leone. PhD Dissertation, Rheinische Friedrich-Wilhelms-Universität Bonn, Bonn, Germany. https:// nbn-resolving.org/urn:nbn:de:hbz:5-62192

Bonuedi, I., Kamasa, K., \& Opoku, E. E. O. (2020). Enabling trade across borders and food security in Africa. Food Security, 12(5), 1121-1140. https://doi.org/10.1007/s12571-020-01095-y

Burke, M., Bergquist, L. F., \& Miguel, E. (2019). Sell Low and Buy High: Arbitrage and Local Price Effects in Kenyan Markets. The Quarterly Journal of Economics, 134(2), 785-842. https://doi. org/10.1093/qje/qjy034

Carletto, C., Corral, P., \& Guelfi, A. (2017). Agricultural commercialization and nutrition revisited: Empirical evidence from three African countries. Food Policy, 67, 106-118. https://doi.org/10.1016/j. foodpol.2016.09.020

Chirwa, E. W., Dorward, A., \& Vigneri, M. (2012). Seasonality and poverty: evidence from Malawi. In S. Devereux, R. Sabates-Wheeler, \& R. Longhurst (Eds.), Seasonality, Rural Livelihoods and Development. Routledge. https://doi.org/10.4324/9780203139820

Cramon-Taubadel, S. V. (2017). The analysis of market integration and price transmission - results and implications in an African context. Agrekon 1-14. https://doi.org/10.1080/03031853.2017.1295655

de Janvry, A., Fafchamp, M., \& Sadoulet, E. (1991). Peasant Household Behaviour with Missing Markets: Some Paradoxes Explained. The Economic Journal, 101(409), 1400-1417. http://www.jstor.org/ stable/2234892

Dercon, S. (2002). Income risk, coping strategies and safety nets. World Bank Research Observer, 17(2), 141-166. https://doi.org/10.1093/ wbro/17.2.141

Dercon, S., \& Krishnan, P. (2000). Vulnerability, seasonality and poverty in Ethiopia. Journal of Development Studies, 36(6), 25-53. https://doi.org/10.1080/00220380008422653

Devereux, S., Vaitla, B., \& Swan, S. H. (2008). Seasons of Hunger: Fighting Cycles of Starvation Among the World's Rural Poor. Pluto Press and ACF International Network. https://doi.org/10. 1017/CBO9781107415324.004

Devereux, Sabates-Wheeler, R., \& Longhurst, R. (2012). Seasonality, Rural Livelihoods and Development (S. Devereux, R. SabatesWheeler, \& R. Longhurst (eds.)). Earthscan. https://doi.org/10. 4324/9780203139820

Dorosh, P. A., Stifel, D., \& Minten, B. (2003). Transaction costs and agricultural productivity : implications of isolation for rural poverty in Madagascar. IFPRI Discussion Paper, 56. http://ideas. repec.org/p/fpr/mssddp/56.html

Dossou-Yovo, E. R., Baggie, I., Djagba, J. F., \& Zwart, S. J. (2017). Diversity of inland valleys and opportunities for agricultural development in Sierra Leone. PLOS ONE, 12(6), e0180059. https://doi.org/10.1371/journal.pone.0180059

Drescher, L. S., Thiele, S., \& Mensink, G. B. M. (2007). A New Index to Measure Healthy Food Diversity Better Reflects a Healthy Diet Than Traditional Measures. The Journal of Nutrition, 137(3), 647-651. https://doi.org/10.1093/jn/137.3.647 
Ecker, O. (2018). Agricultural transformation and food and nutrition security in Ghana: Does farm production diversity (still) matter for household dietary diversity? Food Policy, 79(June), 271-282. https://doi.org/10.1016/j.foodpol.2018.08.002

Fafchamps, M., \& Hill, R. V. (2005). Selling at the farmgate or traveling to market. American Journal of Agricultural Economics, 87(3), 717-734. https://doi.org/10.1111/j.1467-8276.2005.00758.x

FEWS NET. (2017). Sierra Leone staple food market fundamentals (Issue September). USAID \& Famine Early Warning Systems Network.

Gboku, M. L. S., Davowa, S. K., \& Gassama, A. (2017). Sierra Leone 2015 Population and Housing Census: Thematic Report on Agriculture. Statistics Sierra Leone, Freetown, October, 41. https://sierraleone.unfpa.org/en/publications/sierra-leone-2015population-and-housing-census-thematic-report-agriculture

Gilbert, C. L., Christiaensen, L., \& Kaminski, J. (2017). Food price seasonality in Africa: Measurement and extent. Food Policy, 67, 119-132. https://doi.org/10.1016/j.foodpol.2016.09.016

Handa, S., \& Mlay, G. (2006). Food consumption patterns, seasonality and market access in Mozambique. Development Southern Africa, 23(4), 541-560. https://doi.org/10.1080/03768350600929249

Headey, D., Hirvonen, K., Hoddinott, J., \& Stifel, D. (2019). Rural Food Markets and Child Nutrition. American Journal of Agricultural Economics, 101(5), 1311-1327. https://doi.org/10.1093/ajae/aaz032

Hirvonen, K., Hoddinott, J., Minten, B., \& Stifel, D. (2017). Children's Diets, Nutrition Knowledge, and Access to Markets. World Development, 95, 303-315. https://doi.org/10.1016/j.worlddev.2017.02.031

Jacoby, H. G. (2000). Access to Markets and the Benefits of Rural Roads. The Economic Journal, 110(465), 713-737. https://doi. org/10.1111/1468-0297.00562

Jacoby, H. G., \& Minten, B. (2009). On measuring the benefits of lower transport costs. Journal of Development Economics, 89(1), 28-38. https://doi.org/10.1016/j.jdeveco.2008.06.004

Johnston, D., Stevano, S., Malapit, H. J., Hull, E., \& Kadiyala, S. (2018). Review: Time Use as an Explanation for the AgriNutrition Disconnect: Evidence from Rural Areas in Low and Middle-Income Countries. Food Policy, 76(January 2016), 8-18. https://doi.org/10.1016/j.foodpol.2017.12.011

Kennedy, G., Ballard, T., \& Dop, M. (2010). Guidelines for measuring household and individual dietary diversity. Food and Agriculture Organization of the United Nations. http://www. fao.org/3/a-i1983e.pdf

Khandker, S. R., Baqui Khalily, M. A., \& Samad, H. A. (2012). Seasonal hunger and its mitigation in north-west Bangladesh. Journal of Development Studies, 48(12), 1750-1764. https:// doi.org/10.1080/00220388.2012.720369

Khandker, S. R., \& Mahmud, W. (2012). Seasonal Hunger and Public Policies: Evidence from Northwest Bangladesh. The World Bank. https://doi.org/10.1596/978-0-8213-9553-0

Khandker, S. R., \& Samad, H. A. (2016). Is Seasonal Hunger a Distant Memory in Bangladesh? Revisiting Earlier Evidences Empirical Study on Risk and Poverty in Bangladesh. JICA-RI Working Paper No. 110. https://www.jica.go.jp/jica-ri/publication/workingpaper/ jrft3q000000270a-att/JICA-RI_WP_No.110.pdf

Komatsu, H., Malapit, H. J. L., \& Theis, S. (2018). Does women's time in domestic work and agriculture affect women's and children's dietary diversity? Evidence from Bangladesh, Nepal, Cambodia, Ghana, and Mozambique. Food Policy, 79(February), 256-270. https://doi.org/10.1016/j.foodpol.2018.07.002

Koppmair, S., Kassie, M., \& Qaim, M. (2017). Farm production, market access and dietary diversity in Malawi. Public Health Nutrition, 20(2), 325-335. https://doi.org/10.1017/S1368980016002135

Maxwell, D. G., \& Caldwell, R. (2008). The Coping Strategies Index: Field Methods Manual (2nd ed., Issue January). Cooperative for Assistance and Relief Everywhere, Inc. (CARE). https://documents. wfp.org/stellent/groups/public/documents/manual_guide_proced/ wfp211058.pdf
Ministry of Agriculture, Forestry, and F. S., \& Ministry of Health and Sanitation. (2016). Sierra Leone food-based dietary guidelines for healthy eating. http://www.fao.org/fileadmin/user_upload/ foodbased/docs/sierra-leone-food-based-dietary-guidelines-forhealthy-eating.pdf

Ministry of Health and Sanitation, \& Action Against Hunger. (2017). Sierra Leone National Nutrition Survey 2017. Ministry of Health and Sanitation, Freetown, Sierra Leone. https://reliefweb.int/ sites/reliefweb.int/files/resources/Sierra\% 20Leone\% 20National\%20Nutrition\%20Survey\%202017_Final\%20Report\% 20-\%20signed.pdf

Moser, C., Barrett, C., \& Minten, B. (2009). Spatial integration at multiple scales : Rice markets in Madagascar. Agricultural Economics, 40, 281-294. https://doi.org/10.1111/j.1574-0862.2009. 00380. $\mathrm{x}$

Muthini, D., Nzuma, J., \& Qaim, M. (2020). Subsistence production, markets, and dietary diversity in the Kenyan small farm sector. Food Policy, May, 101956. https://doi.org/10.1016/j.foodpol. 2020.101956

Ochiai, T. (2017). Customary land tenure, large-scale land acquisitions and land reform in Sierra Leone. In Faculty of Law Discussion papers, University of Kyoto (2017/06/26). http://www.shd. chiba-u.jp/glblcrss/Discussion_Papers/pdf/Customary_Tenure and_Large-Scale_Land_Aquisitions_in_Sierra_Leone.pdf

Ogutu, S. O., Gödecke, T., \& Qaim, M. (2019). Agricultural Commercialisation and Nutrition in Smallholder Farm Households. Journal of Agricultural Economics, 71(2), 534-555. https://doi. org/10.1111/1477-9552.12359

Pasqualino, M. M., Thilsted, S. H., Phillips, M. J., \& Koroma, A. S. (2016). Food and nutrition security in Sierra Leone with a focus on fish in Tonkolili District. Penang, Malaysia: WorldFish. Program Report: 2016-23. http://pubs.iclarm.net/resource_centre/ 2016-23.pdf

Pushak, N., \& Foster, V. (2011). Sierra Leone's Infrastructure: A Continental Perspective. In Policy Research Working Paper (Issue 5713). https://openknowledge.worldbank.org/handle/ $10986 / 3478$

Renkow, M., Hallstrom, D. G., \& Karanja, D. D. (2004). Rural infrastructure, transactions costs and market participation in Kenya. Journal of Development Economics, 73(1), 349-367. https:// doi.org/10.1016/j.jdeveco.2003.02.003

Ruel, M. T., \& Alderman, H. (2013). Nutrition-sensitive interventions and programmes: How can they help to accelerate progress in improving maternal and child nutrition? In the Lancet. https://doi.org/10.1016/S0140-6736(13)60843-0

Saha, A. (1994). A two-season agricultural household model of output and price uncertainty. Journal of Development Economics, 45(2), 245-269. https://doi.org/10.1016/0304-3878(94)90032-9

Schrieder, G., \& Heidhues, F. (1995). Rural financial markets and the food security of the poor: the case of Cameroon. African Review of Money Finance and Banking, 2(1), 131-154. https:// www.jstor.org/stable/pdf/23027501

Sibhatu, K. T., Krishna, V. V., \& Qaim, M. (2015). Production diversity and dietary diversity in smallholder farm households. Proceedings of the National Academy of Sciences of the United States of America, 112(34), 10657-10662. https://doi.org/10. 1073/pnas. 1510982112

Sibhatu, K. T., \& Qaim, M. (2017). Rural food security, subsistence agriculture, and seasonality. PLOS ONE, 12(10), 1-15. https:// doi.org/10.1371/journal.pone.0186406

Sibhatu, K. T., \& Qaim, M. (2018). Review: The association between production diversity, diets, and nutrition in smallholder farm households. Food Policy, 77(April), 1-18. https://doi.org/10. 1016/j.foodpol.2018.04.013

Statistics Sierra Leone. (2014). 2011 Sierra Leone Integrated Household Survey Report, Freetown, Sierra Leone. https://www. 
humanitarianresponse.info/sites/www.humanitarianresponse. info/files/assessments/slihs2011_integrated_report_current-1_ formatted_latest_.pdf

Statistics Sierra Leone. (2019a). Sierra Leone Integrated Household Survey (SLIHS) Report 2018. Statistics Sierra Leone. https:// www.statistics.sl/images/StatisticsSL/Documents/SLIHS2018/ SLIHS_2018_New/sierra_leone_integrated_household_ survey2018_report.pdf

Statistics Sierra Leone. (2019b). Sierra Leone Multidimensional Poverty Index 2019. Statistics Sierra Leone, Oxford Poverty andHuman Development Initiative, United Nations Development Programme. https://ophi.org.uk/wp-content/uploads/Sierra_ Leone_MPI_2019_final.pdf

Statistics Sierra Leone, \& UNICEF Sierra Leone. (2017). Sierra Leone Multiple Indicator Cluster Survey 2017: Survey findings report. 584. https://www.statistics.sl/images/StatisticsSL/ Documents/sierra_leone_mics6_2017_report.pdf

Stephens, E. C., \& Barrett, C. B. (2011). Incomplete Credit Markets and Commodity Marketing Behaviour. Journal of Agricultural Economics, 62(1), 1-24. https://doi.org/10.1111/j.1477-9552. 2010.00274.x

Stifel, D., \& Minten, B. (2017). Market Access, Well-being, and Nutrition: Evidence from Ethiopia. World Development, 90, 229-241. https://doi.org/10.1016/j.worlddev.2016.09.009

Taqi, F., Vinnie-Wilson, M., \& Vandi, A. (2017). Sierra Leone 2015 Population and Housing Census: Thematic report on gender. Statistics Sierra Leone, Freetown, October, 41. https://www.statistics. sl/images/StatisticsSL/Documents/Census/2015/s1_2015_phc_ thematic_report_on_education_and_literacy.pdf

Thiele, S., \& Weiss, C. (2003). Consumer demand for food diversity: Evidence for Germany. Food Policy, 28(2), 99-115. https://doi. org/10.1016/S0306-9192(02)00068-4

UNDP. (2016). Human Development Report 2016: Human Development for Everyone. United Nations Development Programme, New York, USA. http://hdr.undp.org/sites/default/files/2016_ human_development_report.pdf

Usman, M. A., \& Callo-Concha, D. (2021). Does market access improve dietary diversity and food security? Evidence from Southwestern Ethiopian smallholder coffee producers. Agricultural and Food Economics, 9(1), 1-21. https://doi.org/10.1186/ s40100-021-00190-8

Vaitla, B., Devereux, S., \& Swan, S. H. (2009). Seasonal hunger: A neglected problem with proven solutions. PLoS Medicine, 6(6). https://doi.org/10.1371/journal.pmed.1000101

von Braun, J., \& Kennedy, E. (1995). Agricultural commercialization, economic development, and nutrition (J. von Braun \& E. Kennedy (eds.)). Published for the International Food Policy Research Institute (IFPRI) by Johns Hopkins University Press. brary.ifpri.org/ digital/collection/p15738coll2/id/129374

von Grebmer, K., Bernstein, J., Hammond, L., Patterson, F., Sonntag, A., Klaus, L., Fahlbusch, J., Towey, O., Foley, C., Gitter, S., Ekstrom, K., \& Fritschel, H. (2018). 2018 Global Hunger Index: Forced Migration and Hunger. Welthungerhilfe; and Dublin: Concern Worldwide.

WFP. (2017). Road and market access, and household food security in Nepal. https://docs.wfp.org/api/documents/WFP0000068990/download/?_ga=2.259627530.1699024281. 1550682617-1052267393.1550682617

World Bank Climate Change Knowledge Portal. (2019). Historical Climate Data. https://climateknowledgeportal.worldbank.org/ country/india\% $0 \mathrm{~A}$

World Food Programme. (2011). The State of Food Security and Nutrition in Sierra Leone 2011. In Comprehensive Food Security and Vulnerability Analysis (CFSVA). http://documents.wfp.org/ stellent/groups/public/documents/ena/wfp250158.pdf

World Food Programme. (2015). State of Food Security in Sierra Leone 2015: Comprehensive Food Security and Vulnerability Analysis
(Issue October). https://documents.wfp.org/stellent/groups/public/ documents/ena/wfp288316.pdf?iframe

Zanello, G., Shankar, B., \& Poole, N. (2019). Buy or make? Agricultural production diversity, markets and dietary diversity in Afghanistan. Food Policy, 87(February), 101731. https://doi.org/ 10.1016/j.foodpol.2019.101731

Zeller, M., Schrieder, G., von Braun, J., \& Heidhues, F. (1997). Rural finance for food security for the poor: implications for research and policy (No. 4; Food Policy Review). International Food Policy Research Institute (IFPRI). http://ebrary.ifpri.org/cdm/ ref/collection/p15738coll2/id/125890

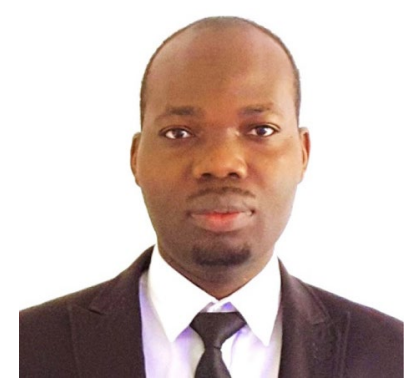

Isaac Bonuedi was a Junior Researcher at the Center for Development Research (ZEF), University of Bonn, Germany, where he obtained a $\mathrm{PhD}$ (Development and Applied Agricultural Economics) in 2021. He also holds masters degrees in Economics from the University of Southern Denmark, Denmark, and the Kwame Nkrumah University of Science and Technology (KNUST), Ghana. He previously worked as Assistant Lecturer as well as Teaching and Research Assistant at the Department of Economics, KNUST. His research cuts across Agriculture and Development Economics, and International Economics. His current research focuses on nutrition-sensitive agriculture, markets, food security, and international trade.

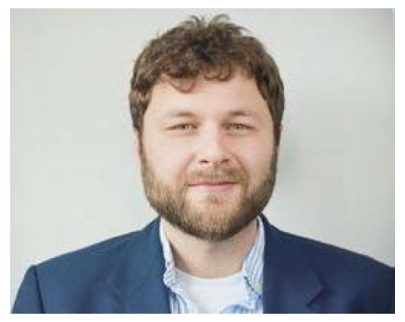

Dr. Lukas Kornher obtained his $\mathrm{PhD}$ from the University of Bonn in 2015. He has extensive work experience in food price volatility and markets in general. He is currently working at the University of Bonn's Center for Development Research (ZEF) as the Coordinator of the Food Monitor Project and Senior Research Fellow. He previously worked at the University of Kiel as a PostDoctoral Researcher.

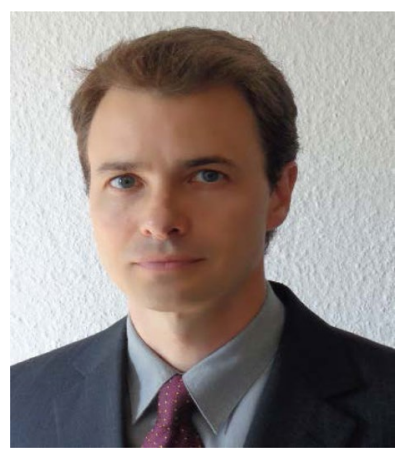

Nicolas Gerber is senior researcher at the Center for Development Research (ZEF), University of Bonn since 2007. He holds a $\mathrm{PhD}$ in Economics from the University of New South Wales, Australia. Over the last 20 years Nicolas has researched broadly on the management of biodiversity, land and water resources and their interlinkages with poverty, food security, nutrition and health. He has led teams investigating the causes of rural nutrition at the intersection of water, sanitation and agriculture and in the context of agricultural innovation. His current research team investigates urban nutrition in Africa in connection with the organization of the local food system, food safety and quality along the supply chains, and consumers' food behavior. 